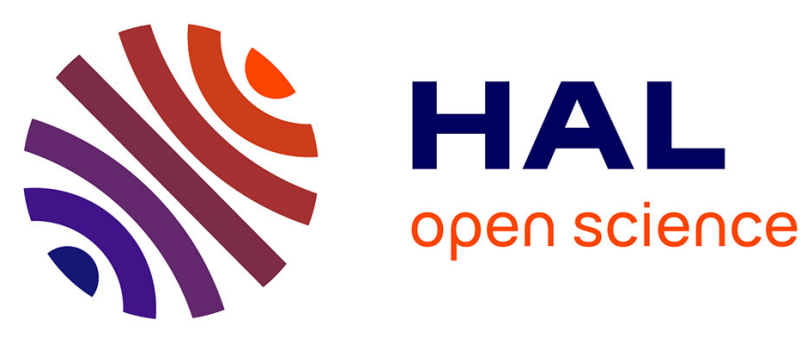

\title{
Gadachrili Gora: Architecture and organisation of a Neolithic settlement in the middle Kura Valley (6th millennium BC, Georgia)
}

Caroline Hamon, Mindia Jalabadze, Tata Agapishvili, Emmanuel Baudouin, Irakli Koridze, Erwann Messager

\section{To cite this version:}

Caroline Hamon, Mindia Jalabadze, Tata Agapishvili, Emmanuel Baudouin, Irakli Koridze, et al.. Gadachrili Gora: Architecture and organisation of a Neolithic settlement in the middle Kura Valley (6th millennium BC, Georgia). Quaternary International, 2016, 395, pp.154-169. 10.1016/j.quaint.2015.01.055 . hal-03150494

\author{
HAL Id: hal-03150494 \\ https://hal.science/hal-03150494
}

Submitted on 10 Jan 2022

HAL is a multi-disciplinary open access archive for the deposit and dissemination of scientific research documents, whether they are published or not. The documents may come from teaching and research institutions in France or abroad, or from public or private research centers.
L'archive ouverte pluridisciplinaire HAL, est destinée au dépôt et à la diffusion de documents scientifiques de niveau recherche, publiés ou non, émanant des établissements d'enseignement et de recherche français ou étrangers, des laboratoires publics ou privés. 


\title{
Gadachrili Gora: Architecture and organisation of a Neolithic settlement in the middle Kura Valley (6th millennium BC, Georgia)
}

\author{
Caroline Hamon ${ }^{\text {a, }}{ }^{\text {, }}$ Mindia Jalabadze ${ }^{\mathrm{b}}$, Tata Agapishvili ${ }^{\mathrm{b}}$, Emmanuel Baudouin ${ }^{\mathrm{c}, \mathrm{d}}$, \\ Irakli Koridze $^{\mathrm{b}}$, Erwann Messager ${ }^{\mathrm{e}}$ \\ ${ }^{a}$ CNRS, UMR 8215 Trajectoires, Maison de l'archeologie, 21 allee de l'Université, 92023 Nanterre cedex, France \\ ${ }^{\mathrm{b}}$ Georgian National Museum, Rustaveli Av. 3, Tbilisi 5, Georgia \\ ${ }^{c}$ PhD Université Paris IV-Sorbonne, ED 126, UMR 8167, Orient et Méditerranee, France \\ ${ }^{d}$ UMR 7192, Proche-Orient Caucase: langues, archéologies et cultures (PrOCauLAC), France \\ ${ }^{\mathrm{e}}$ CNRS, UMR 7264, CEPAM Université de Nice Sophia Antipolis POle Universitaire de Saint Jean d'Angély, 24 Avenue des diables bleus, o6357 Nice cedex 4 , \\ France
}

\section{a r t i c lein fo}

\section{Article history:}

Available online 7 April 2015

\section{Keywords:}

Neolithic

Georgia

Caucasus

Gadachrili Gora

Kura Valley

Architecture

\begin{abstract}
a bstract
The mechanisms responsible for the emergence of a farming economy in Transcaucasia have been the subject of much debate since the 1970's. This debate has focused particularly on the role played by NearEastern influences in the development of the Shulaveri-Shomu culture, which emerged in the Kura Basin at the end of the 7th millennium BC. Recently, archaeological investigations have been conducted by a Georgian-French team in Gadachrili Gora, one of four "Shulaveri group" tells located on a tributary of the Chrami River in the Kvemo-Kartli plain of Georgia. Dating evidence clearly places the first levels of this tell in an early phase of the development of the culture, between 5920 and 5720 Cal BC. These investigations provide new evidence regarding the processes of neolithisation, especially in terms of settlement organisation and the architectural techniques used at the time. Several occupation levels feature connected circular units, of various sizes, together with "courtyards", which were used as circulation $\mathbf{e}$ or waste disposal areas. The density and organisation of these structures display different patterns for the two distinct levels of occupation preserved. Evidence from the deepest occupation levels suggests a high density of occupation in the settlement, with complex episodes of destruction and rebuilding. Several building techniques were used, including different types of bricks laid in various patterns depending on wall types. In addition, there is evidence for the use of the "bauge" construction technique, which was unknown in the region until now. Parallels established with the construction techniques of Northern Iran and Mesopotamia contribute to the discussion regarding the processes underlying the emergence of the Shulaveri culture. Moreover, the high number of storage structures and the discovery of organized built spaces dedicated to storage raise many questions about the status of the site, the organisation of agricultural practices, and the relationship of these populations to the hydrographic network within the area.
\end{abstract}

\section{Introduction}

Several hypotheses have been forwarded to explain the appearance of the first Neolithic cultures in the Southern Caucasus.

\footnotetext{
${ }^{*}$ Corresponding author.

E-mail addresses: caroline.hamon@mae.cnrs.fr (C. Hamon), mindiajal@gmail.com (M. Jalabadze), atatella@yahoo.com (T. Agapishvili), emmanuel.baudouin@ parissorbonne.fr (E. Baudouin), ere_koridze@posta.ge (I. Koridze), erwan. messager@cepam.cnrs.fr (E. Messager).
}

The mechanisms for the emergence of a farming economy are still under discussion today, in terms of chronology, genesis, territorial occupation and subsistence economy. The first archaeological expeditions conducted in the 1960's and 1970's on both sides of the Azerbaijani e Georgian border (Dzhaparidze and Dzhavakhishvili, 1975; Kiguradze, 1986; Narimanov, 1987), focused on the Neolithic sites of the middle Kura Basin where the so-called Shulaveri-Shomu culture was identified and initially dated to the 6th millennium BC. More recently, excavations conducted in the Araxe valley revealed certain close links between the Aratashen and 

Aknashen sites and those of the middle Kura. The existence of a single Aratashen-Shulaveri-Shomu culture, with regional specificities, has also been proposed (Badalyan et al. 2007). In addition, recent excavations have provided some early dates which indicate a possible emergence of this culture at the very end of the 7th millennium BC.

In the last decade, our knowledge of the neolithisation of the Southern Caucasus has been greatly added to through the definition of regional specificities (Badalyan et al., 2010; Guliyev and Nishiaki, 2010; Lyonnet et al., 2012). However, the origins of this culture, and its internal chronological evolution, still have to be defined, particularly with regard to links with Anatolia and Mesopotamia. Its fully agro-pastoral economy and its round, mud-brick architecture initially suggested an importation of building techniques from the Near-East. But this model of colonization from the southern regions of Anatolia and Mesopotamia has been countered by a model involving an in situ emergence of a Neolithic economy. This hypothesis relies principally on specificities in the building techniques and material culture. To take but one example, the absence of ceramics and of painted pottery in the foundation phases of some sites is taken to support the hypothesis of an indigenous origin for the Neolithic. In addition, very little is known about the potential relationships between this culture and late Mesolithic hunteregatherer populations, or other Neolithic populations, occupying neighbouring territories and ecological zones such as the volcanic plateau of the Central Caucasus, or the subtropical shores of the Black Sea (Niebieridze, 1986; Kiguradze et Menabde, 2004; Hamon, 2008; Arimura et al., 2010).

Studies in Georgia have the potential to contribute significantly to our overall understanding of the neolithisation of the Caucasus and, more broadly, of the evolution between human groups and their environment during the Holocene. Occupying the northern part of Transcaucasia, Georgia is located between the two main Caucasus ranges. It is situated at the interface between the grasssteppe plains to the north of the Black Sea (Ukraine, Russia) and the Near-Eastern regions (Anatolia, Mesopotamia), each characterised by different neolithisation processes. The eastern part of the country is centred on the semi-arid valleys of the Kura and Alazani, while the Colchis Plain occupies the western part. Because of this geographical situation, the excavation of Gadachrili Gora (Kura Valley, Georgia) offers new opportunities to contribute to the debate on the neolithisation of the Caucasus, focusing on the settlement organisation and economy of the north eastern part of the Shulaveri-Shomu cultural area.

\section{Gadachrili Gora, general outline}

As part of the so-called "Shulaveri " group, the site of Gadachrili Gora offers an excellent opportunity to examine the organisation of the territory, and the relationship between different settlements in the same area, in terms of contemporaneity and economic complementarity.

\subsection{Location and preservation}

The so-called «Shulaveri » group (including the eponymous site) consists of four sites in the Kwemo-Kartli Plain, centred along a seasonal tributary of the Khrami River, the Shulaveris Ghele (Fig. 1). The site is located to the south-east of the village of Irimi (district of Marneuli; coordinates $41^{\circ} 23^{0} 26^{00} \mathrm{~N}$; $44^{\circ} 49^{0} 16^{00} \mathrm{E}$; $360 \mathbf{e} 370 \mathrm{~m}$ a. s. 1.). It occupies a central position between the sites of Shulaveris Gora, Imiris Gora and Dangreuli Gora. These sites have provided the chronology and most of our knowledge regarding this culture in Georgia (Kiguradze, 1986). The site of Gadachrili Gora is the only one of the four sites which was not excavated in the 1970's by the team from the Georgian National Museum in charge of the conservation and scientific exploitation of documentation and archaeological material (Djavakhishvili et al. 1975).

It is traversed by the river Shulaveris Ghele, a tributary of the Khrami River, which has cut a deep, wide canyon (7e $8 \mathrm{~m}$ deep and $35 \mathbf{e} 40 \mathrm{~m}$ wide) through the middle of the site. As a result, the central part of the former settlement has been completely destroyed. The south-eastern side of the site, and a small quantity of cultural deposits on the right bank of the river, have survived (approximately $1 / 3$ of the site). A longitudinal EeW section across the whole site is representative of the general stratigraphy of the site (Fig. 2).

\section{Brief history of archaeological campaigns on the site}

Because of the constant erosion and progressive destruction of the site by the river, the Georgian State Museum has conducted a series of archaeological investigations on the site. In the 1960s, the Lower Kartli Archaeological Expedition of the S. Janashia Georgian State Museum excavated a small test trench on Gadachrili Gora and also conducted field walking in order to recover surface finds (Djavakhishvili et al. 1975).

In 2006e2007, the Marneuli Archaeological Expedition of the Georgian National Museum carried out small-scale, archaeological investigations (conducted by M. Jalabadze). A topographic plan of the site and its adjacent territory was prepared. The surface of the settlement was divided into $10 \times 10 \mathrm{~m}$ grid squares which were further subdivided into $2 \times 2 \mathrm{~m}$ squares. A test trench $(8 \times 3 \mathrm{~m})$ was dug in the north-eastern corner of the surviving part of the hillock, which, along with a natural vertical section, has allowed us to determine the stratigraphy of the upper level.

In 2012e2013, further archaeological investigations were conducted in the framework of a joint project between the Georgian National Museum and the French National Centre for Scientific Research (LIA Gates, excavations conducted by C. Hamon \& M. Jalabadze), and supported by different institutions (Georgian Wine Agency) and programs (ANR Kura In Motion \& Orimil). To the first trench opened in 2007, two further trenches were added in the southern part of the site: Trench 2, with an area of $25 \mathrm{~m}^{2-},(5 \times 5 \mathrm{~m})$ and Trench 3, with an area of $12.5 \mathrm{~m}^{2}(5 \times 2.5 \mathrm{~m})$.

\subsection{Dating}

The erosion of the upper levels of the site prevents us from determining with precision the existence, or otherwise, of occupation post-dating the Neolithic. It also prevents us from determining the exact duration of the occupation of the site. Nonetheless, as Gadachrili Gora was the only tell that was not excavated in the 1960/1970's by the Kvemo-Kartli expedition, it presented a good opportunity to re-examine part of the Shulaveri group chronology.

Surface finds of a small number of pottery sherds, dated to the Iron Age, attest to the frequentation of the site at a later date. The preserved occupation levels do not show any traces of later disturbance. The ceramic finds are scarce and fragmented, and, for the moment, feature very little decoration. The typological and technological characteristics of the pottery are in accordance with the general observations made for assemblages belonging to the Shulaveri-Shomu culture.

Two distinct levels (also known as "horizons") have been preserved and were identified in the general stratigraphy of the site in 2006. They are separated by a thin, sterile layer of green clay (see below US 2043 and 100). For each horizon, several occupation phases have been identified through stratigraphy. It appears that a short time span separates the two horizons. Horizon 2 corresponds to the earliest occupation phase in this part of the site (Fig. 3). 

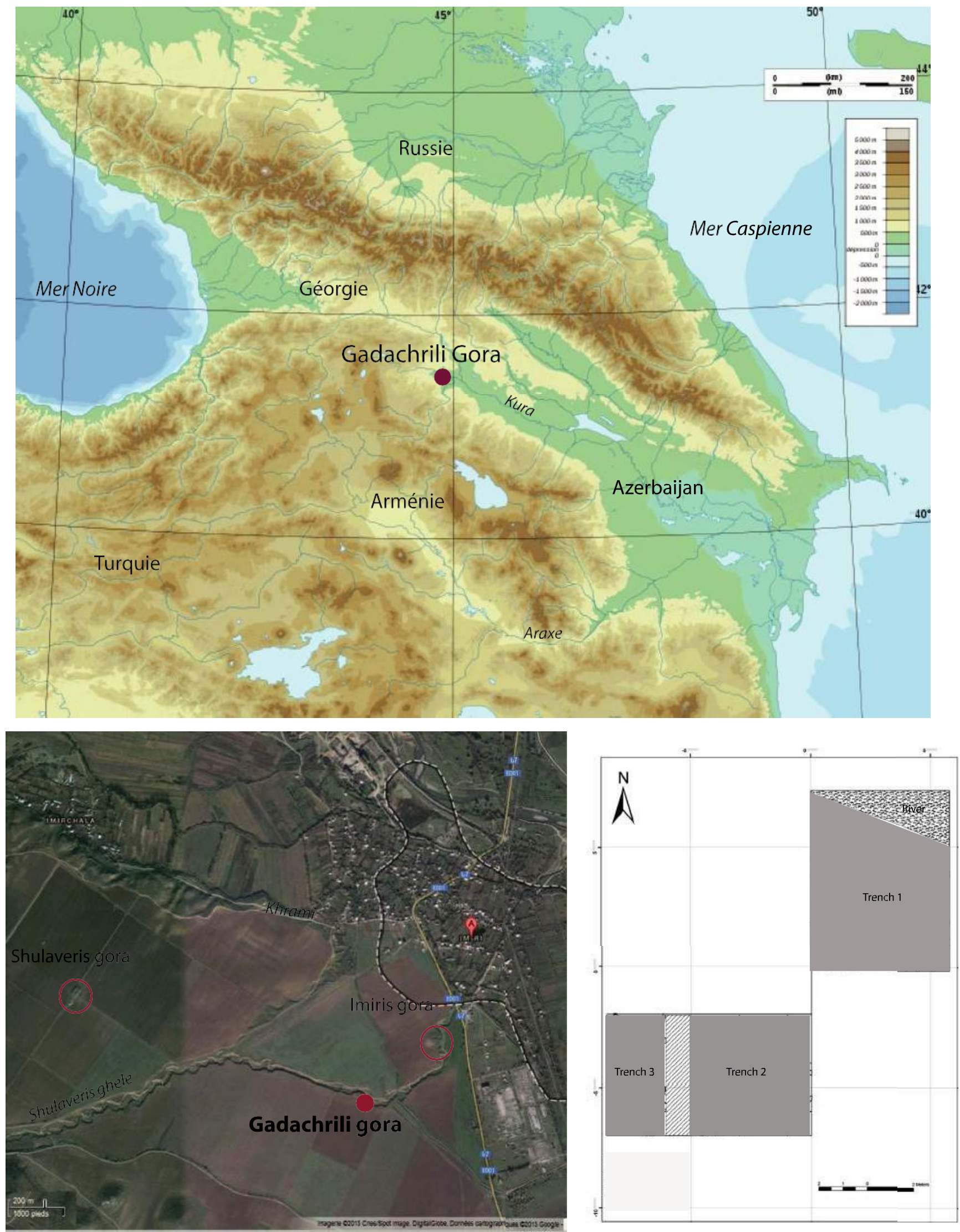

Fig. 1. Location map of Gadachrili Gora with locations of Trenches $1 \mathbf{e} 3$. 


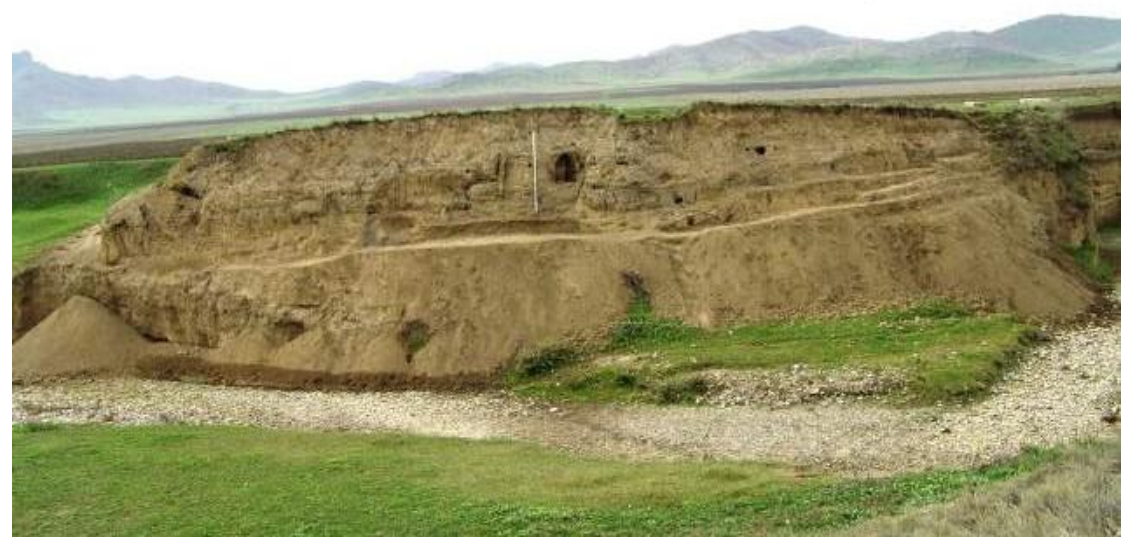

Fig. 2. Longitudinal section cut through the site by the river. The step corresponds to the bottom limit of the Neolithic layers (photo GNM).

Initial radiocarbon dates have been obtained on samples from Horizon 1 in the 2006 trench. A second series of dates has been obtained by AMS carried out on seeds and charcoal from the lowest occupation layers of Horizon 2 in Trench 1. After calibration at 2 sigma, three out of four of the dates clearly place the establishment of the site in quite an early phase of the development of ShulaveriShomu culture. The first two levels of the settlement are dated to the first quarter of the 6th millennium BC, between 5920 and 5650 Cal BC (Fig. 4). On the basis of these dates, it has not been possible to determine the time span between the two horizons. Nonetheless, these dates clearly correspond to the first stages of the ShulaveriShomu culture. It is important to take this parameter into account, as our observations on the organisation of the settlement and on its architecture have to be discussed in this context.

\section{What is happening in the Shulaveri group? A novel} architecture and organisation of domestic space

\section{Excavations 2006e2007: first discoveries and general stratigraphy of the site}

Two principal horizons were tentatively identified on the site, separated from one another by a clay stratum $(15 \mathbf{e} 25 \mathrm{~cm}$ thick, depending on the trenches). The $2006 \mathbf{e} 2007$ excavations focused

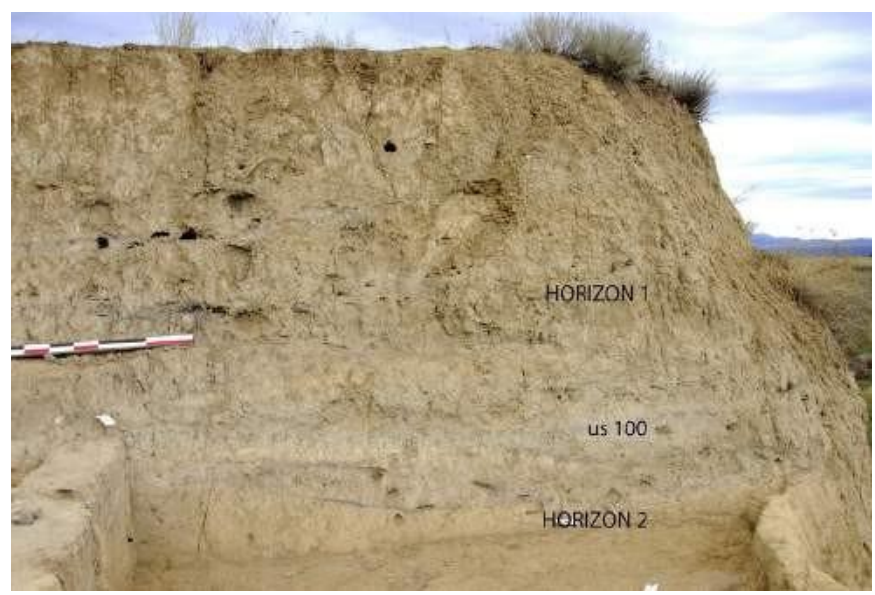

Fig. 3. South-north section of Trench 1 ; Horizons 1 and 2 separated by a blue sterile clay layer (us 100) (photo C. Hamon). (For interpretation of the references to colour in this figure legend, the reader is referred to the web version of this article.) on the occupation layers of the lowest horizon, in a trench located to the east of the preserved area.

The earliest preserved levels were found directly under the humic layer: They measure $0.50 \mathbf{e} 0.60 \mathrm{~m}$ in thickness and are composed of a yellow, clay mass mixed with ash and isolated bricks, corresponding to the destruction levels of former buildings. The first remains of circular walls (squares: CB-4,9; DB-0,1,2,5,6,7) were uncovered at a depth of about $0.35 \mathbf{e} 0.40 \mathrm{~m}$ below the ground surface level of the trench. The installation level of the upper horizon was identified at around $1.25 \mathrm{~m}$ below the ground surface level of the trench.

Three buildings, organized in a single row, have been unearthed in the trench. Their diameters range from 1.5 to $2.5 \mathrm{~m}$ (Fig. 5). The foundation wall of the main building was made up of a double row of bricks. All of the buildings were constructed of mud brick and were plastered inside and outside with a hard, yellowish, clay render. The bricks are similar to the bricks used in the Kvemo-Kartli settlements of the same period (so-called plano-convex bricks and plain rectangular bricks). Their sizes vary between 38 and $40 \times 15 \mathbf{e} 20 \$ \mathbf{e} 10 \mathrm{~cm}$. Often dark and light bricks are used alternately during construction. The main building was constructed first, and additional walls were added later. Visible signs of reconstruction and renovation of the buildings, as is common in Shulaveri-Shomu settlements, were observed in two cases. The main building (N1) seems to have been renovated three times.

To the south of this row of buildings, part of a courtyard has been excavated. In this "open area", which was probably used for circulation, a large flat zone was found to be covered with refuse (Fig. 6). Significant assemblages of ceramics, lithics and bone material were recovered from this trench (Fig. 7).

\section{Horizon 1: Trenches 2 and 3}

In 2013, two new trenches (Trenches 2 and 3) were opened. The main objective of the excavations was to confirm the presence of occupation levels to the south-west of Trench 1, corresponding to the Horizon 1 identified in 2006. A secondary aim was to clarify the organisation of the buildings and the function of the "open areas". What were the extents of these open areas, and how are they related to the buildings? Should they be interpreted as refuse areas and/or circulation zones between different ranges of buildings or to the southern limit of the settlement?

During the excavations in Trenches 2 and 3, several buildings were found together with several storage structures. A large 


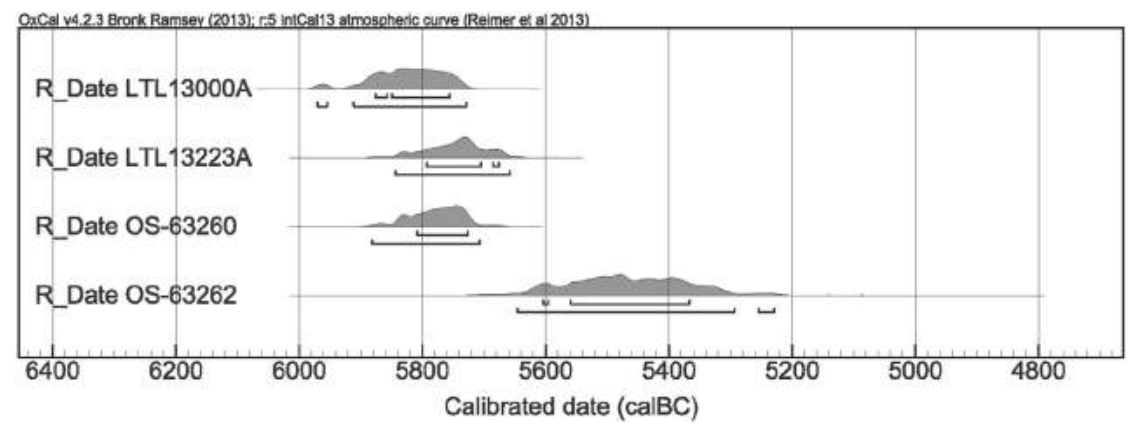

Fig. 4. ${ }^{14} \mathrm{C}$ dates for Horizons 1 and 2 in Gadachrili Gora (2 sigma, calibrated).

circular building, measuring nearly six metres in diameter, is directly associated with smaller circular buildings to the east and to the north of the area (Fig. 8). Several storage structures found inside and outside this so-called "main" building show that they were generally common in Gadachrili Gora. To the west, in Trench 3, several walls may indicate a subdivision of the internal space of the "main" building. Finally, a series of associated exterior floors to the north and south of the three buildings in Trench 2 provide significant information on building layout and the management of space within the site (Fig. 8).

\subsection{Preliminary phase before building construction}

Several levels have been discovered which predate the construction of the first buildings (Fig. 9). The Horizon 1 building phase, as in trench 1 (see below), overlies a sterile level of grey clay (US 2043). This clay layer in turn overlies a compact mud layer (US 2044), probably corresponding to the abandonment or destruction of the previous building phases. This destruction layer has also been identified in Trench 1 (US 2043 and 2044 corresponding respectively to US 100 and 101 in trench 1).

This level was entirely covered by an ash layer (US 20324 2050) on top of which two somewhat later buildings (US 2003 and 2004) were constructed. To the south-east, the builders added a clay layer (US 2042) to compensate for the slope. This layer was covered by an ash layer (US 2049) on top of which a mud-brick wall was erected (US 2002).

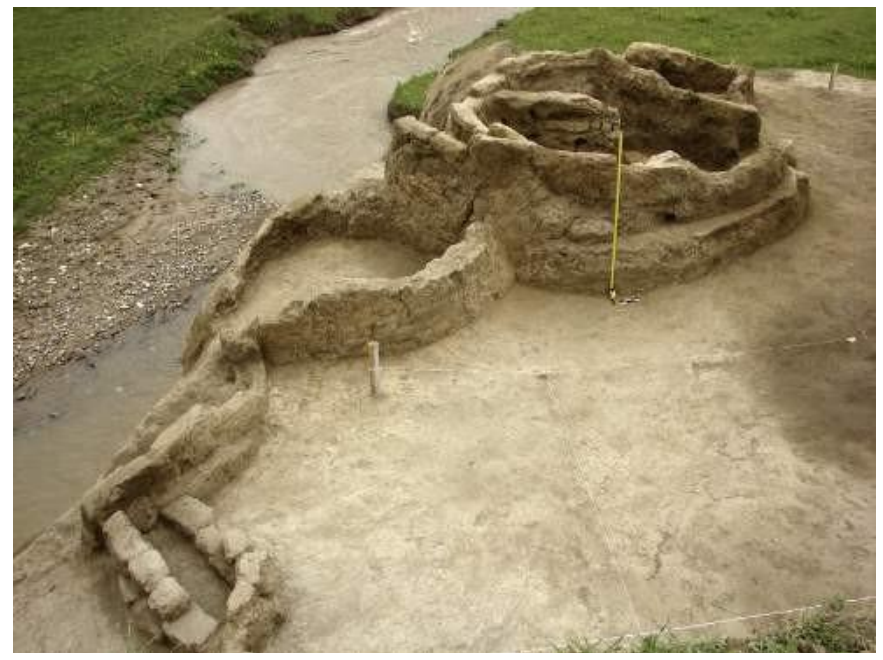

Fig. 5. Trench 1: Buildings uncovered in 2006e2007; view from the south (photo GNM).

\section{Buildings and structures: organisation and construction} techniques

In Trench 2, there is evidence that the three excavated buildings were inhabited at the same time (Fig. 8):

- Buildings 2003, 2004 were both constructed on top of an ash layer (US 2032) and the storage structure (US 2002) on top of another ash layer (US 2049).

- Building 2003 is attached to the render coating of Building 2004.

- Structure 2002 is attached to the render coating of Building 2003.

A relative chronology can therefore be established: Buildings 2004, 2003 were both constructed before the storage structure 2002. However, these different building phases must have been

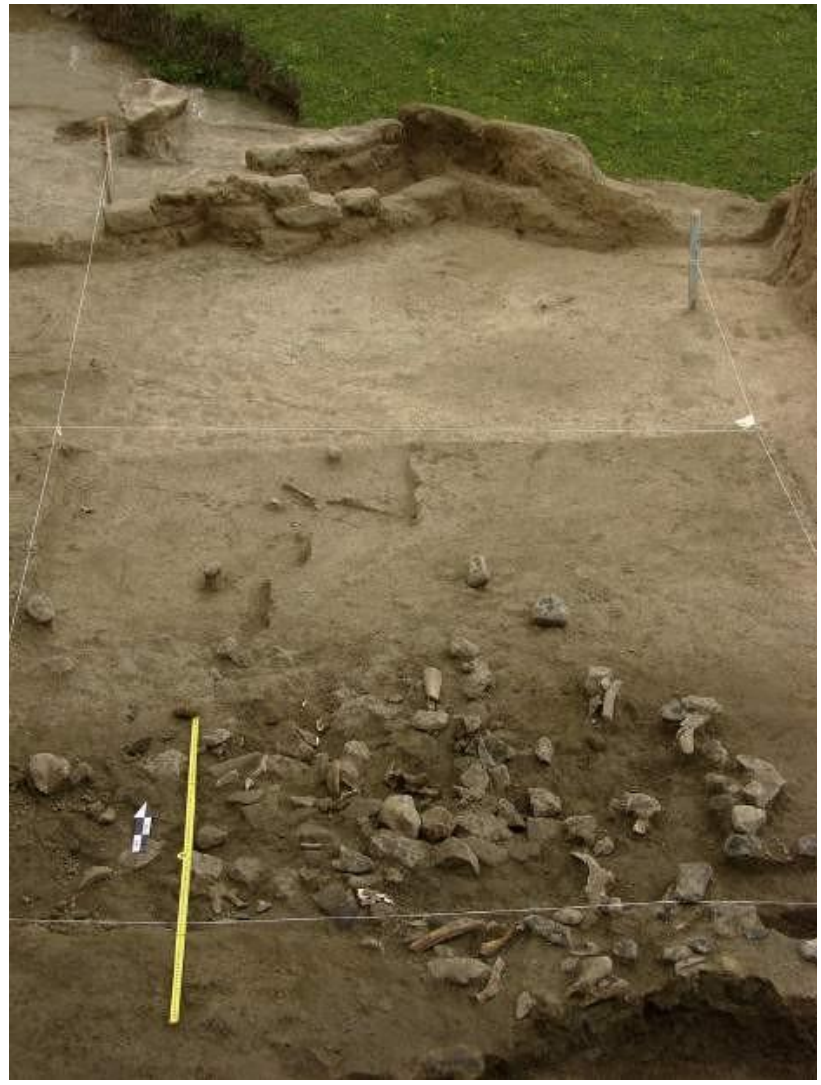

Fig. 6. Courtyard with refuse area in the southern part of Trench 1 (photo GNM). 

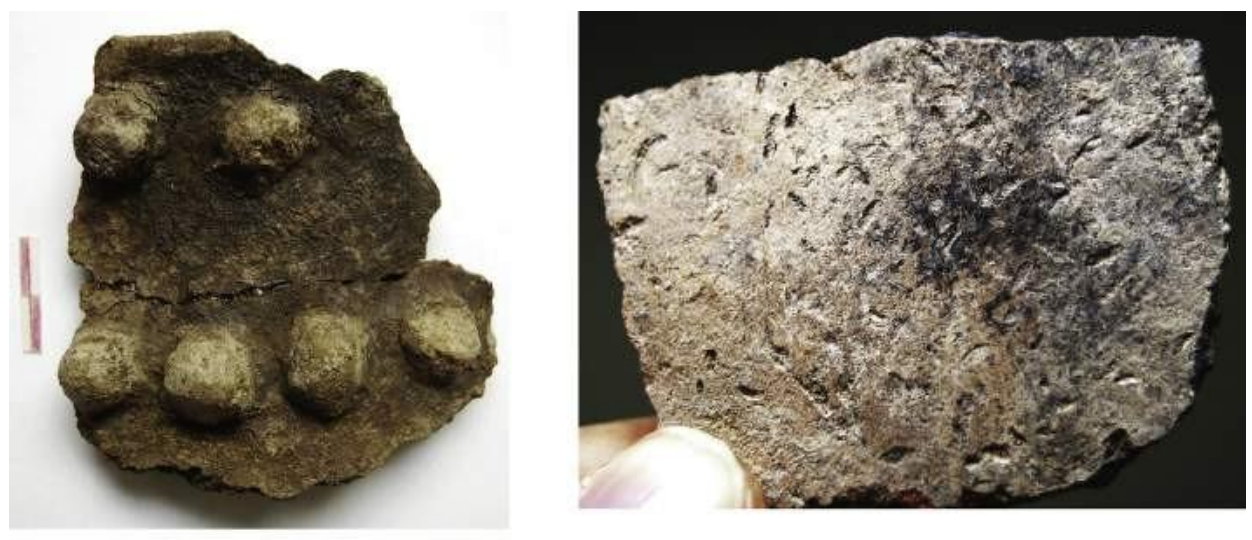
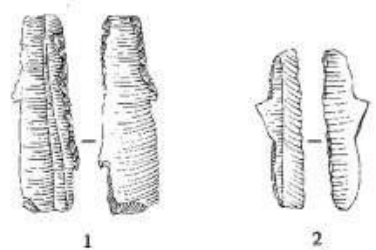

2

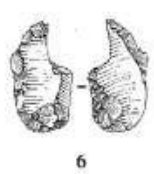

7

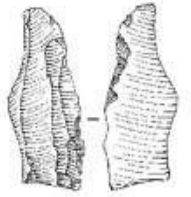

3

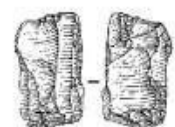

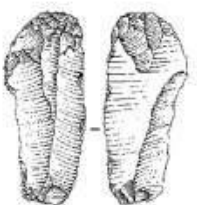

4
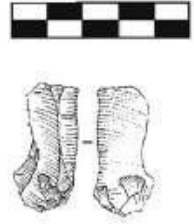

5
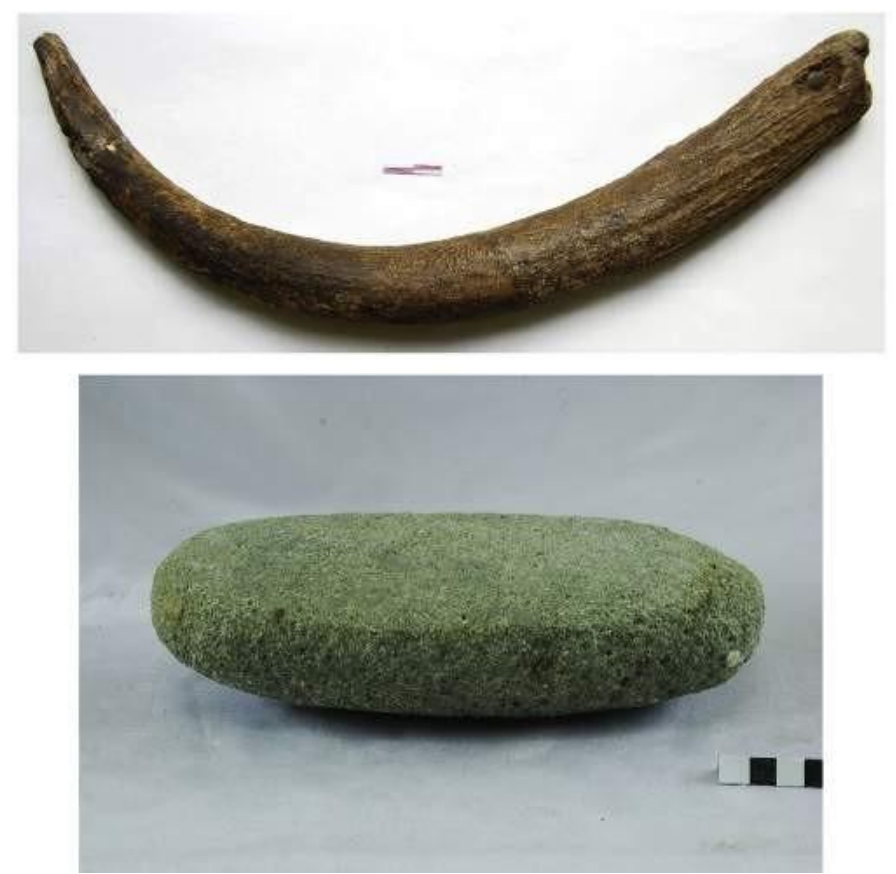

Fig. 7. Sample of finds from Trench 1, Horizon 1, $2006 \mathbf{e} 2007$ excavations (photo and drawings GNM)

very close to each other in time, and they must have been in use, at least partially, at the same time.

A variety of architectural techniques have been identified in Horizon 1 at Gadachrili Gora:

- Building 2004 (Fig. 10) has a diameter of about 6 m. In Trench 2, a portion of the building, measuring $3.40 \mathrm{~m}$ long (north-south) and $1.40 \mathrm{~m}$ wide, was revealed, while the northern part of its wall was found in Trench 3 . The wall width varies between 30 and $50 \mathrm{~cm}$. The building was constructed using elongated, flat, rectangular mud bricks laid in a regular stretcher bond. The three surviving courses of bricks are bound together using a mortar made of yellow clay tempered with organic material. This technique is uncommon in the Shulaveri-Shomu culture, 


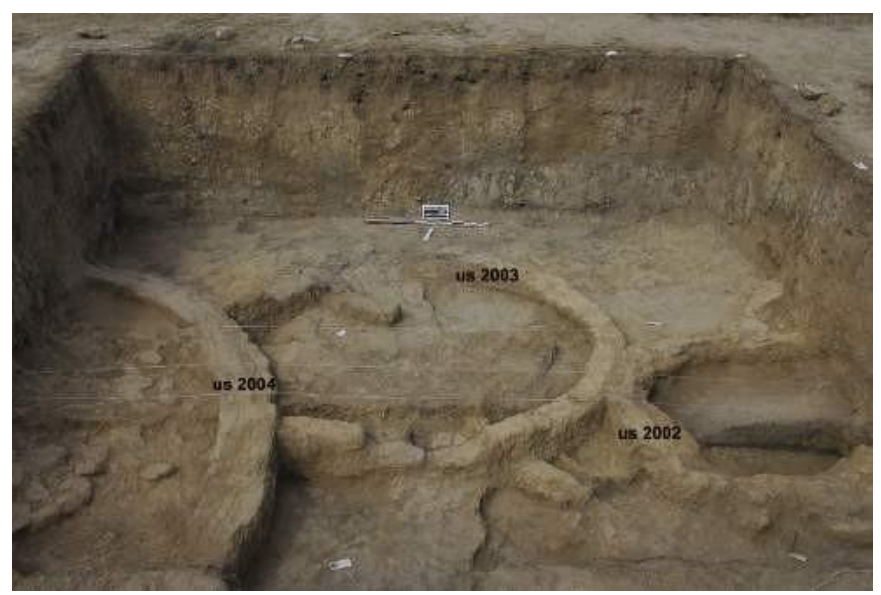

Fig. 8. Trench 2: General view of the three buildings from the south (photo C. Hamon).

and was only used at the base of one building in Shulaveri Gora (Kiguradze, 1986, p. 18e19). However, it finds several parallels in Central Mesopotamia (Choga Mami (Oates, 1969, pl. XXII)), and Iran (Choga Banut (Kantor, 1978, pl. IIa)).

- Building 2003 (Fig. 8) is oval in plan and measures $2.101 .90 \mathrm{~m}$ with a wall width of around $19 \mathrm{~cm}$. It was built using sun-dried, plano-convex, mud bricks. All are a standard size $(40 \times 99 \times \mathrm{cm})$, and are arranged in a stretcher pattern in the single surviving course. This technique is well known in the Shulaveri-Shomu culture and occurs, for example, at Aruchlo (Hansen and Mirtskhulava, 2012, p. 66, Fig. 93). The inner and outer faces of the walls were rendered with plaster composed of a hard brown/yellow mortar tempered with organic material. The building had two doors, one to the north and one to the south. Although the north door was poorly preserved, the threshold of the south door was complete and is composed of two mud bricks. A thin layer of mortar covers the exposed faces of these bricks and the bricks of the associated walls. The smoothing of the top of the mud bricks indicates that they acted as a threshold or door step (Fig. 11).

- Structure 2002 has a diameter of about $1.8 \mathrm{~m}$ and a wall width of around $14 \mathrm{~cm}$. It was built using the same technique as Building 2003 , but the size of the mud bricks is different $(2614 \times 8 \mathrm{~cm})$. The walls were covered with a brown/orange render composed of carbonate residues abundantly tempered with organic material. This plaster was applied in a very thick layer ( $8 \mathrm{~cm}$ thick) (Fig. 12) to the inner and outer faces of the wall (as observed in the south-eastern part of the building) in order to waterproof the structure. These characteristics have led us to interpret this building as a large storage structure.

In Trench 3, the southern wall of the small building 3013 appears to be connected to the northern part of Building 2004 (Fig. 13). It has an estimated diameter of less than $2 \mathrm{~m}$, although only a very small part of it has been excavated. Constructed of mud-brick, the wall of the building represents the rebuilding of a pre-existing wall at a lower stratigraphic level (US 3027).

32.3. Inside each building: interior structures and occupation phases

32.31. Building 2004. The floor of Building 2004(US 2035) was the last real soil level excavated during the 2013 campaign in Trench 2.

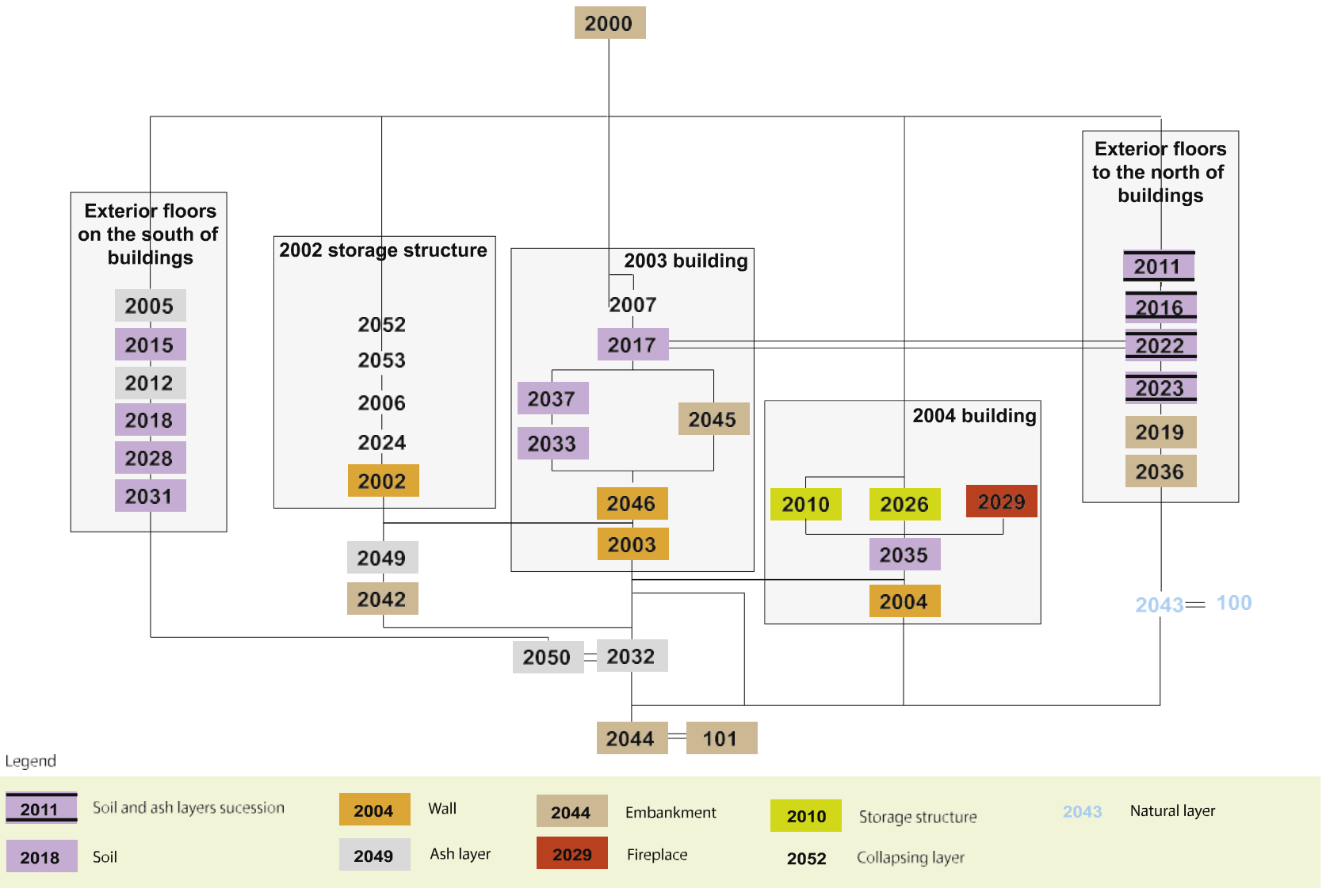

Fig. 9. Stratigraphic diagram of the main layers and structures in Trench 2 (drawing E. Baudoin). 


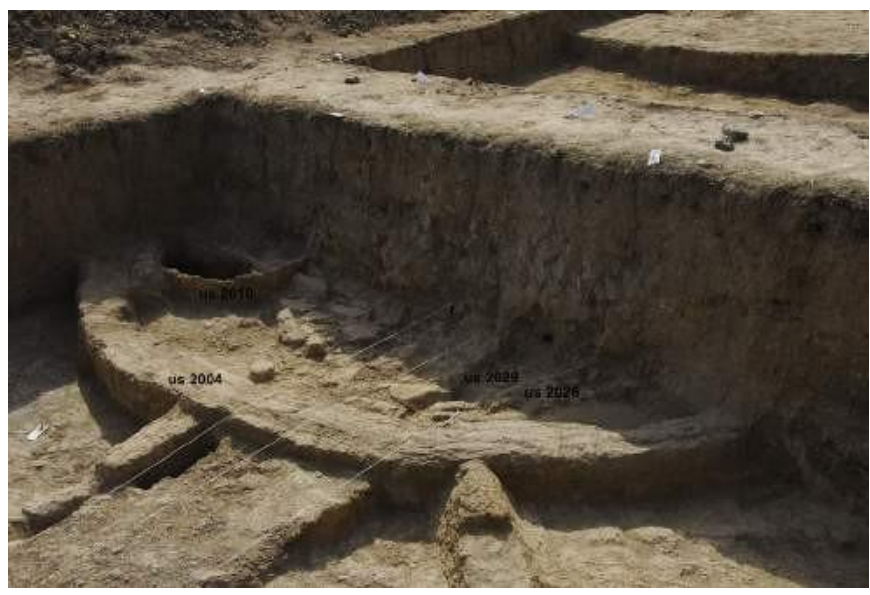

Fig. 10. General view of Building 2004; Trench 2, view from the north-east (photo C. Hamon).

It is a brown, compacted layer with organic and charcoal inclusions. Three structures were in use contemporaneously with this floor:

- Storage structure 2010 , to the southeast of the building, was joined to the wall of building 2004 using mud brick rubble (Fig. 14). This storage structure was oval in plan, measuring $90 \times 70 \mathrm{~cm}$. Its walls $(4 \mathbf{e} 6 \mathrm{~cm}$ thick) were plastered with a brown/orange clay tempered with organic material. Its walls were built by laying quadrangular, flat slabs of clay $(2 \& 25 \mathrm{~cm})$ end-to-end and joining them by smoothing the joints.

- Storage structure 2026 was located in the northern part of the building (Fig. 15). This storage structure had partly collapsed after the subsidence of wall 2004 to the north. It measured $59 \mathrm{~cm} \times 30 \mathrm{~cm}$, and was $20 \mathrm{~cm}$ high. Its walls were covered by a $2 \mathbf{e} 3 \mathrm{~cm}$ thick layer of plaster of the same composition as that in Storage structure US 2010.

- Towards the centre of the building, a small hearth (US 2029), $30 \mathrm{~cm}$ long and $24 \mathrm{~cm}$ wide, was dug directly into the floor.

In the south-eastern part of Trench 3 , the structures excavated occupy what is interpreted as the interior space of Building 2004.

- Four storage structures, which appear to have functioned in pairs, occupy the central area (Fig. 16). Storage structures 3011

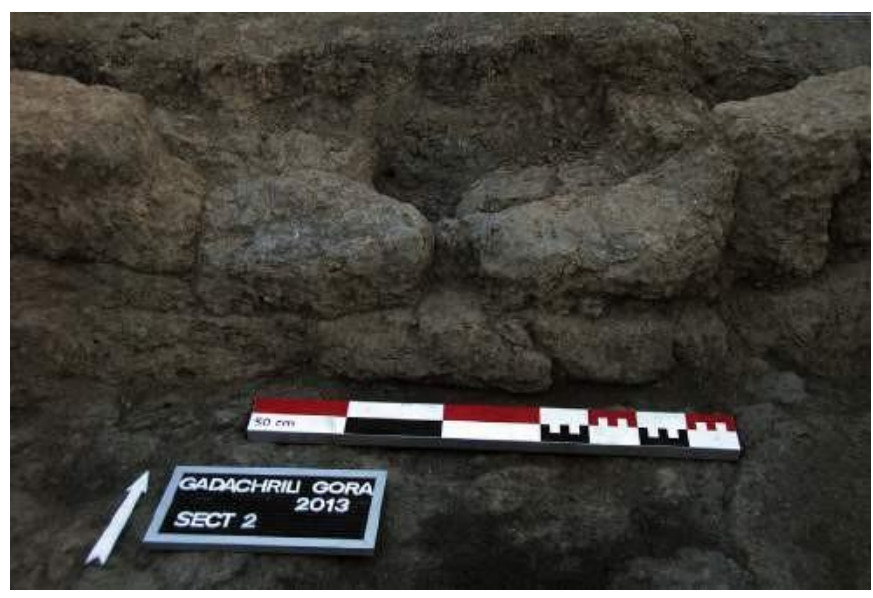

Fig. 11. Detail of the threshold of Building 2003; Trench 2, view from the south (photo C. Hamon).

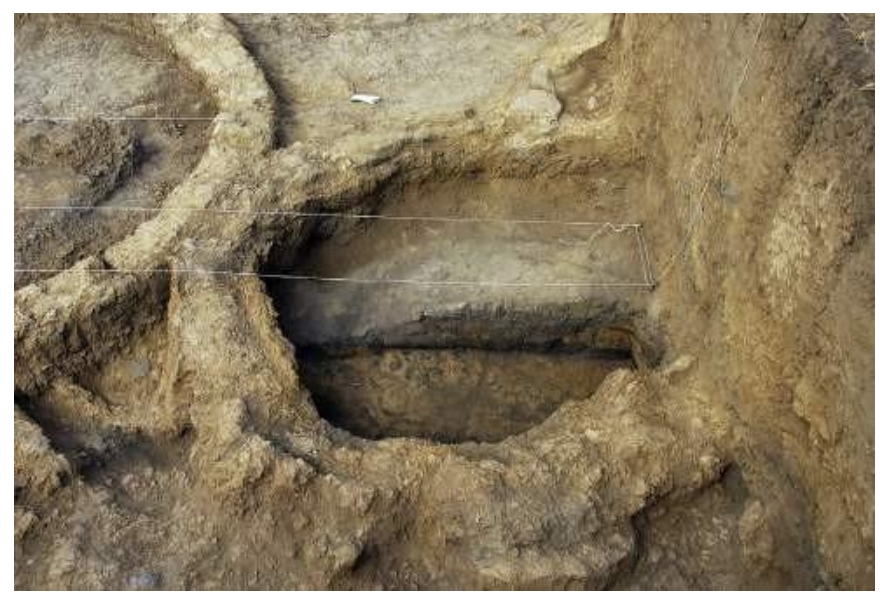

Fig. 12. General view of storage structure 2002; Trench 2, view from the south (photo C. Hamon).

and 3022 are characterised by a double wall, either for insulation purposes or resulting from rebuilding. Their close proximity and their similar dimensions and configurations suggest that they may have functioned in pairs as twin structures. US 3005 and 3007, located on either side of wall 3009, are smaller in size and are probably associated with the same storage area as storage structure 2010 .

- In the southern part of the trench, two circular mud-brick walls are visible (US 3009 \& 3016). They were built using bricks of different sizes and forms: Long rectangular bricks alternate with smaller square bricks. They may represent internal subdivisions within the main building 2004 .

These hypotheses regarding the storage structures need to be clarified through further investigations to the south, as their precise stratigraphic relationship, especially with building 2004, was not possible to determine.

32.3.2. Building 2003. A separation wall (US 2046) occupies the centre of the building, to the east of the north and south doors. It has a north-south orientation and features a curved footprint. It measures $1.86 \mathrm{~m}$ long and $19 \mathrm{~cm}$ thick (Fig. 17). As is the case for the entire building 2003, this wall was erected directly on top of US 2044. Three courses of bricks were preserved (20 cm high).

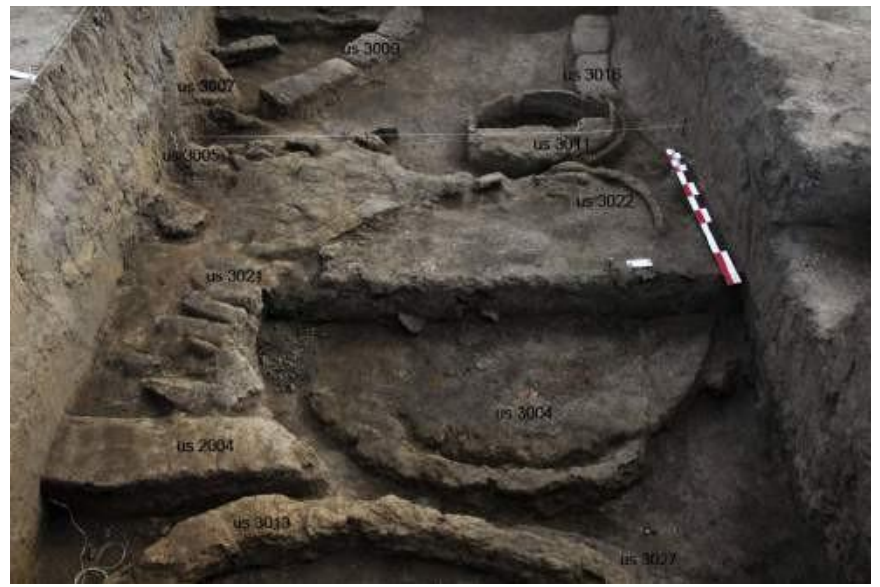

Fig. 13. Trench 3: General view of the structures, view from the north (photo C. Hamon). 
Fig. 14. Detail of Structure 2010 and link with Wall 2004; Trench 2, view from the west (photo C. Hamon).

Stratigraphic analysis of the different layers filling Building 2003 suggest that the western and eastern parts of the building, on either side of the dividing wall 2046, had different functions (Fig. 18):

- To the west of wall 2046, the bottom-most layer consisted of a single fill layer made of brown clay. Above it, the first floor layer (US 2033) was made up of greenish clay with carbonized inclusions. This in turn was overlain by a second floor level (US 2037) composed of compact sediment mixed with frequent charcoal inclusions. These floor levels testify to the regular trampling of the soil and support the hypothesis of a circulation area to the west of Wall 2046.

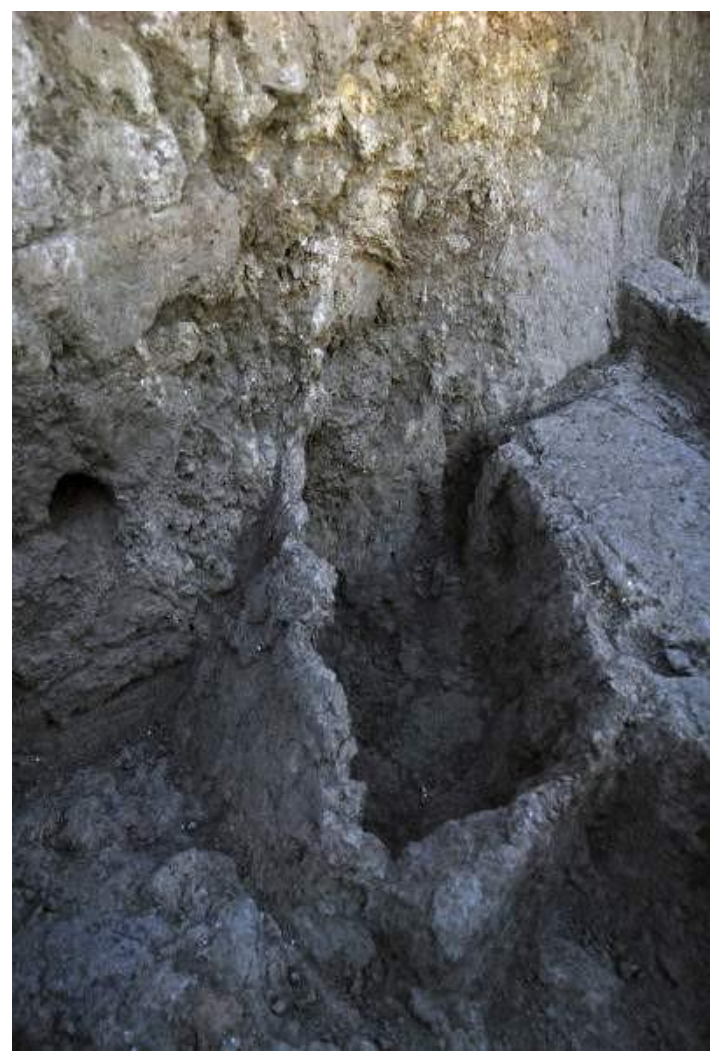

Fig. 15. Detail of Structure 2026; Trench 2, view from south-east (photo C. Hamon).

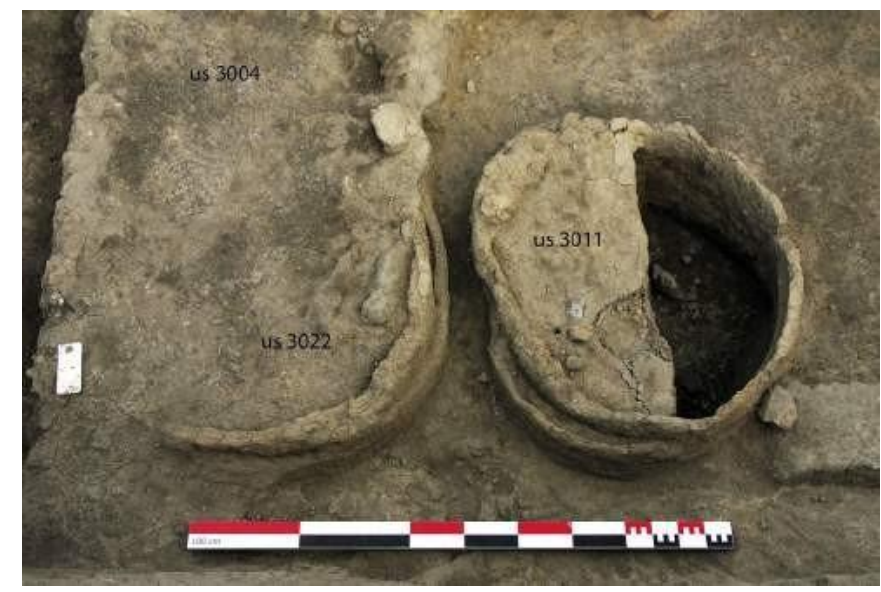

Fig. 16. Pair of storage structures 3011 and 3022; Trench 3, view from the south-east (photo C. Hamon).

- Overlying Floor Level 2037, a new floor was laid down(US 2017), which occupied the surface of the whole building: It features a steeply sloping gradient to the west of wall 2046. The lack of other layers under this floor level to the west of the wall 2046, suggest the existence of an empty space under these layers.

The position of the door to the west of wall 2046, and the steep gradient of the last floor level, both suggest that this area was used as a circulation area between the southern and the northern parts of Trench 2. The eastern part probably had a different, but as yet unknown, function.

32.3. Storage structure 2002. The top layers of Structure 2002 bear witness to its abandonment: US 2006, for example, consists of yellow sediments mixed with collapsed mud bricks and ash which suggest that at the end of its life the mud brick walls partially collapsed into the structure (US 2052 and 2053).

\section{Area organisation and function}

To the north and south of the eastern buildings in Trench 2, a clear alternation of layers is discernible, and partly correlated. The sequencing of these layers, and their function, can be summarised as follows.

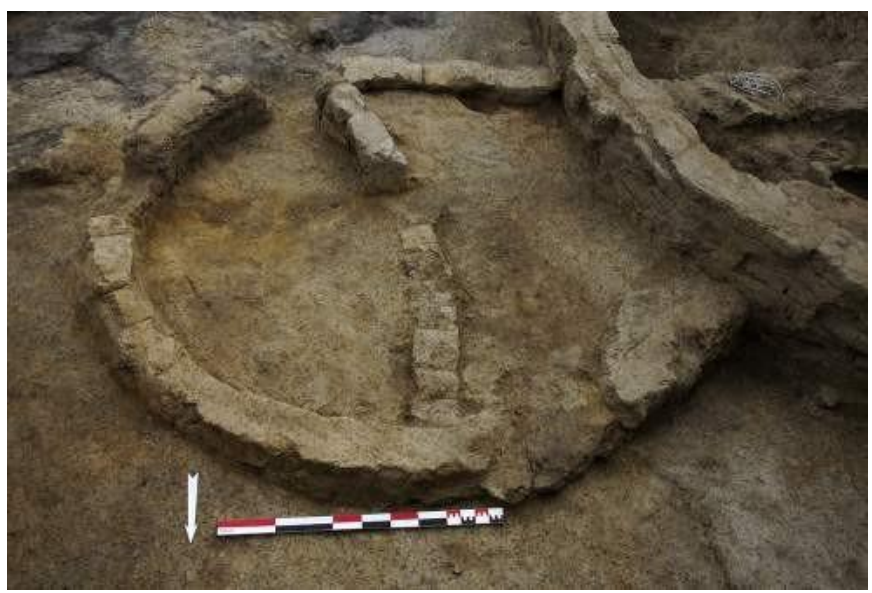

Fig. 17. General view of Building 2003 with Wall 2046 in the centre; Trench 2, view from the north (photo C. Hamon, modified). 


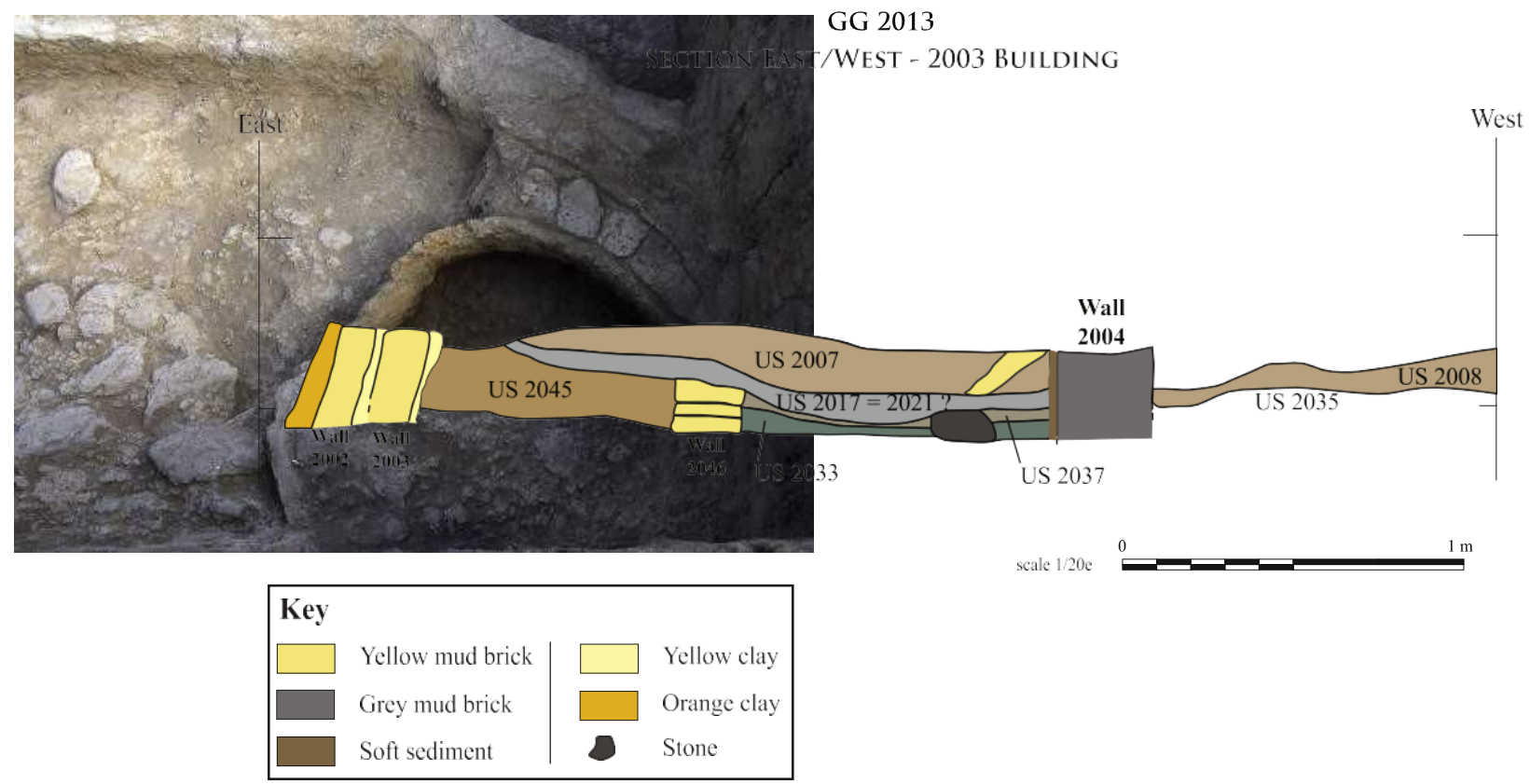

Fig. 18. East-west section of Building 2003; notice the collapse of the layers at the west of the structure (drawings E. Baudoin).

To the north, a "natural", sterile layer (US 2043), has been identified overlying US 2044. The nature and origin of this fine green clay needs to be confirmed by further geo-morphological analyses.

Above it, two fill layers (US 2036 and US 2019) were deposited to level the surface before the laying down of the circulation layers. A succession of four exterior floors (from the bottom up: US 2023, $2022,2016,2011$ ) was used in conjunction with the buildings. Each of these floors is separated from the next by a thin layer of ash. In one example, we can suggest continuity between exterior floor (US 2022) and the interior floor of Building 2003 (US 2017): This provides a clear indication that these layers functioned in conjunction with the building floors.

To the south of the buildings, two floors (US 2031, 2018) were laid on top of an ash layer (US 2050). They seem to have been used at the same time as the buildings as all of the layers are laid against the southern walls of Buildings 2003, 2004.

\subsection{Summary}

A continuous occupation corresponding to Horizon 1 has been identified in the three trenches opened. It is associated with different kinds of buildings and quite a large number of successive floors and related layers.

- The domestic occupation is clearly associated with a large number of storage structures, of different sizes and types, located both inside (in building 2004) and outside (storage pit 2002) the buildings.

- Two ranges of buildings are oriented on an east/west axis in Trenches 1 and $2 / 3$. In parallel, a certain organisation of the buildings is also suggested by the positions of smaller buildings to the north and east of main building 2004, forming a cruciform layout.

- Building 2004 and related structures are located on the highest point of this phase of the occupation of the site. Indeed, all layers in this part of the site (except those inside the building) slope down to the South or to the North. This reinforces the hypothesis that this "main" building had a special status.
- Building 2003, with its two entrances, may have been used as an access way or transition space connecting the southern and northern areas: this interpretation offers an explanation for the absence of structures within the building.

The architectural cohesion of this horizon provides evidence of planned occupation. The abandonment of Horizon 1 was followed by a general destruction of all structures, and the filling up of the entire surface with a brown layer of alluvium and clay (US 2000), situated just under the top soil.

\subsection{Horizon 2: excavation of Trench 1}

Horizon 2 (Trench 1) lies beneath the sterile clay layer that separates it from Horizon 1. It is characterised by a high density of structures which have a complex stratigraphy. Their organisation is in complete contrast with the wide circulation areas and large buildings of Horizon 1 (Fig. 19).

\subsubsection{Rows of buildings}

Three rows of buildings have been excavated in Trench 1; they are oriented on an east-west axis.

At the north, a first row has been partly destroyed by the river. It is composed of six curvilinear walls that survive to a height of $60 \mathrm{~cm}$. It is probable that some of these structures correspond to circular units (US 105,145) but others resemble connecting walls, as suggested by a square brick located at the junction of walls 149 and 157 (Fig. 20). All of these walls, which are $\mathrm{c} .15 \mathrm{~cm}$ wide, have been constructed of plano-convex mud-bricks $(30 \times 13 \times 10 \mathrm{~cm})$, as found on the floor of Building 105.

The remains of two round buildings are visible at the centre of Trench 1 (Fig. 21). They only survive to a height of two courses of mud-brick and were clearly levelled deliberately. In terms of stratigraphy, the lowest level of bricks in these buildings represents the latest episode of building construction of Horizon 2, which immediately underlies the sterile clay layer. Building 137 was constructed after building 135. Their diameters are comparable, being between $1 \mathrm{~m}$ and $1.5 \mathrm{~m}$. Their walls are around $15 \mathrm{~cm}$ wide and are 


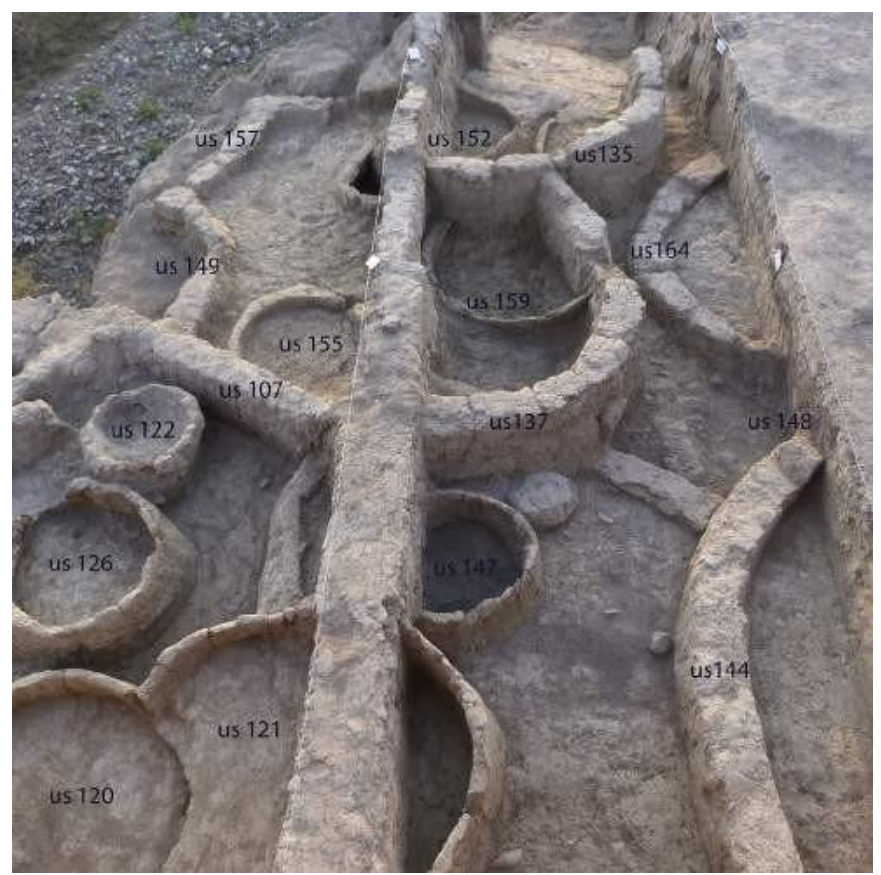

Fig. 19. General view of Trench 1 from the west; note the three rows of circular buildings, the concentration of storage structures in the area to the north-west and the isolated storage structures to the north. Artificial section in centre (photo C. Hamon). constructed of plano-convex mud-bricks of different sizes $(15 \mathbf{e} 20 \mathrm{~cm} \star 0 \mathrm{~cm})$. Both walls were partly constructed on top of the older storage structures 163 and 170; parts of their walls are even incorporated within the walls of 135 and 137.

To the south, a third row of buildings was found. Two circular buildings (US 144 and 164) were well preserved, and a third one was partially destroyed by the river to the east. Their diameters are estimated at between 1.5 and $2 \mathrm{~m}$. The base of these walls (foundations or first building phase) is c. $18 \mathbf{e} 20 \mathrm{~cm}$ wide and constructed of plano-convex mud-bricks $(26 \times 18 \times 5 \mathrm{~cm})$. These buildings were probably levelled and rebuilt, or repaired, as indicated by the east-west section of Trench 1. Overlying these two walls, two other walls, with a slightly different orientation, have been found just under the sterile clay layer (from west to east: US 139, 164, 217 and 140) (Fig. 22). They correspond either to reconstruction phases of Buildings 144 and 164, or to other levelled buildings; further excavations will clarify this point. To the east, Walls 140 and 136, built of mud-bricks, were partly destroyed by the river. To the west, Walls 139 and 217, and the upper part of Wall 164, were difficult to identify and to follow. This was largely due to the fact that they were constructed using a very specific building technique known as "bauge". This technique involves the piling up of unfired clay blocks of different sizes and shapes (Roux and Cammas, 2010): These blocks are composed of clay mixed with organic inclusions (charcoal, bones, etc). The clay used was sometimes sourced directly from anthropic levels or former soils, which make it difficult to distinguish the walls from the surrounding destruction or fill layers (see for example Wall 217) (Fig. 23). This technique corresponds to

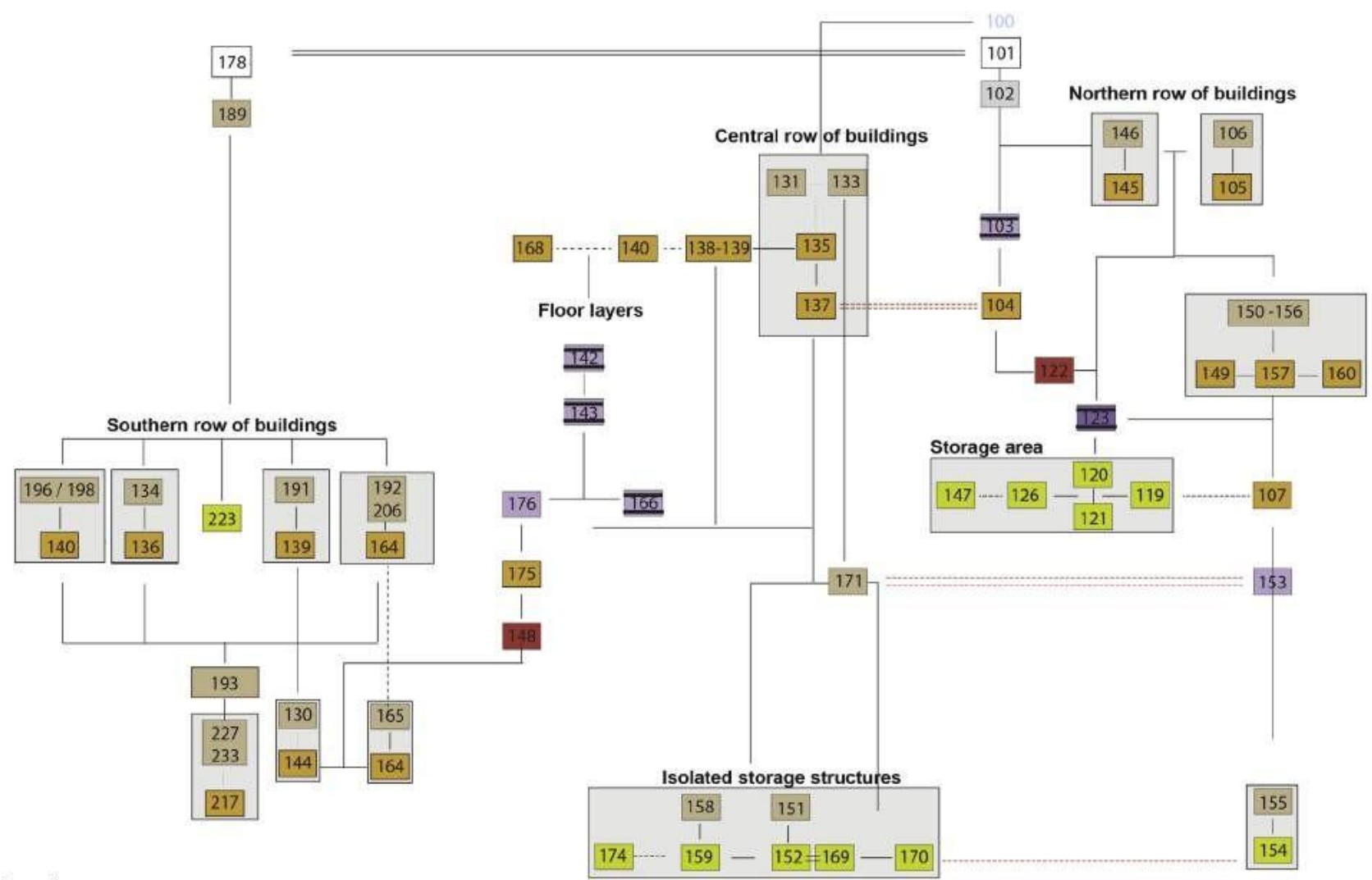

Legend

\begin{tabular}{|c|c|c|c|c|c|c|c|c|c|}
\hline 2044 & Soil and ash layers sucession & 2004 & Wall & 2044 & Embankment 2010 & Storage structure 2043 & Natural layer & - & contemporaneaous structures \\
\hline 2018 & Soil & 2049 & Ash layer & 2029 & Fireplace & Collapsing layer & & & e contemporanec \\
\hline
\end{tabular}

Fig. 20. Simplified stratigraphic diagram for Trench 1 (drawings C. Hamon). 


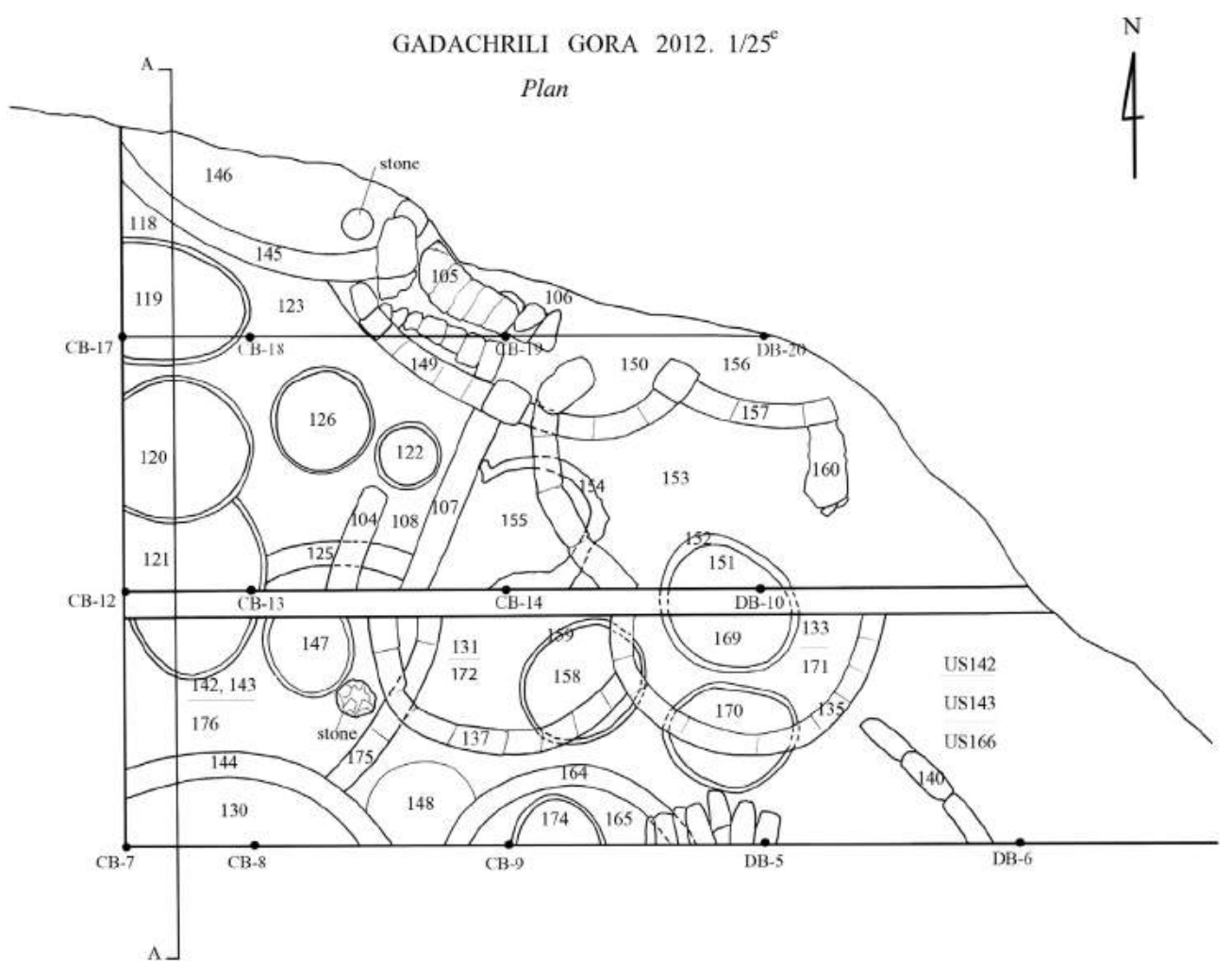

Fig. 21. General plan of Sector 1, 2012 excavations (drawings: GNM and CNRS).

what has been identified in the Ararat basin in Akhnashen under the term "pisé" (Badalyan et al. 2010), but it had not been identified in the middle Kura basin up to now. We propose to use the term "bauge" (with no corresponding term in English), rather than pise, to describe this particular construction technique. Here we follow the precise definition, provided by Aurenche (1977,p. 138e139), for the term "pisé", which normally describes a technique using formwork for the modelling of clay walls and which should not be used as a general term for the building using clay.

\subsubsection{Storage areas}

Between the north and south ranges of buildings, two rectilinear walls follow a similar southwest-northeast orientation (Walls 107 and 175). They connect Wall 149 to the north with Wall 144 to the

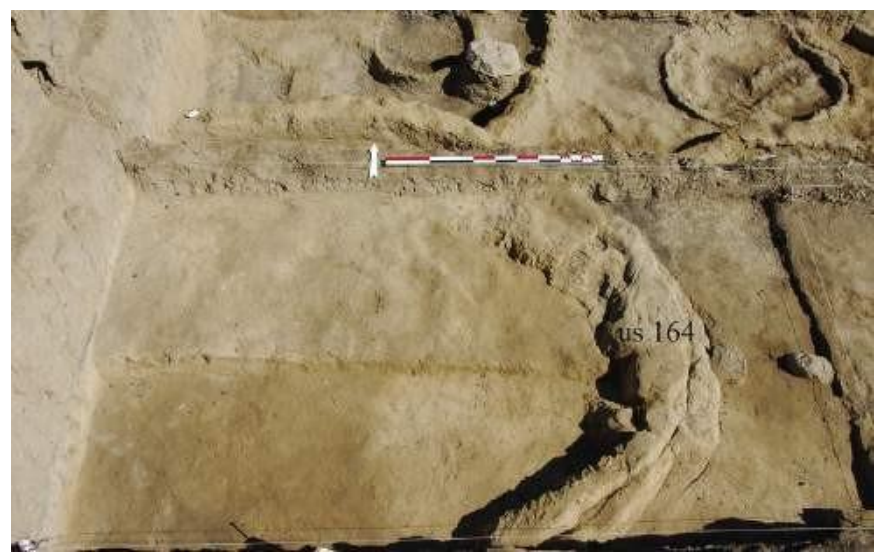

Fig. 22. Wall 164, Trench 1, view from the south: the upper part is constructed using the "bauge" technique (photo C. Hamon). south. Both are built of mud-bricks $(40 \times 20 \times 8 \mathrm{~cm})$, and are c. $20 \mathrm{~cm}$ thick. Although they are not precisely in alignment, they are clearly connected and define a limit between two spaces. A similar wall has also been identified in the longitudinal section of the site, along the river, $2 \mathrm{~m}$ to the West of the edge of Trench 1 . This wall could constitute the western limit of the western storage area.

To the west, the first storage area was clearly organized. It is composed of at least five storage pits $(119,120,121,126,147)$

(Fig. 24). These "pear-shaped" structures are complete and are preserved to a depth of $60 \mathrm{~cm}$ with a maximum diameter of $115 \mathrm{~cm}$ (see US 120). Their walls are built with flat, square blocks of clay, measuring c. $10 \mathrm{~cm}$ square, tempered with organic matter. At the

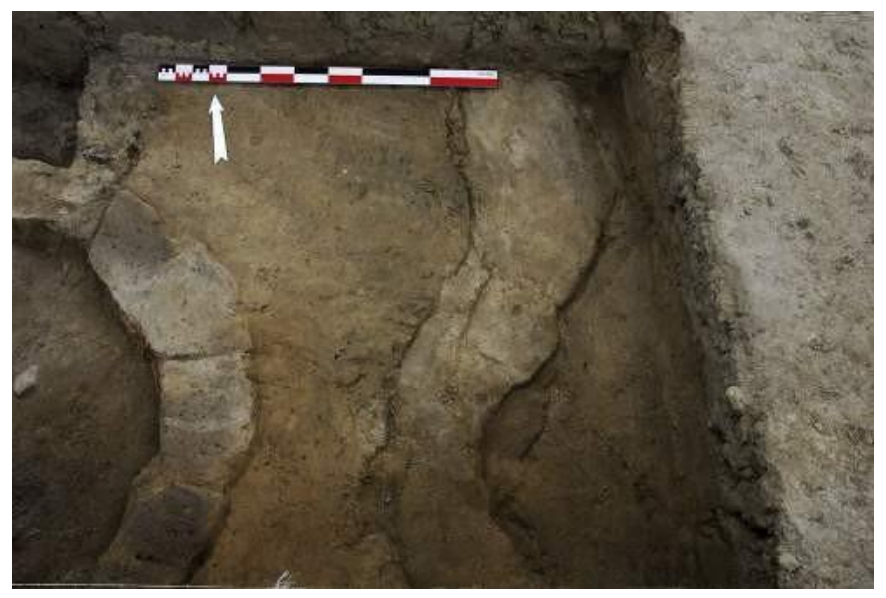

Fig. 23. Examples of "bauge " walls: to the left, Wall 217 constructed with mud blocks made of clay mixed with charcoal and organic material. Trench 1, view from the south (photo C. Hamon). 
base of the structure, the bricks can be up to $5 \mathrm{~cm}$ wide but they do not exceed $2 \mathbf{e} 3 \mathrm{~cm}$ at its summit: it is as if the initial clay blocks had been stretched from bottom to top. Because of the fragility of their walls, these structures must have been used as subterranean storage structures. To the north of Structure 120, a series of small bricks were used to reinforce the structure's wall. This is clear evidence that the whole area was organised around these storage structures. These structures are filled following the same process and sequence as the surrounding layers. For example, Structures 119,120 and 121 share the same fill layers in their first $40 \mathrm{~cm}$, as illustrated in the main north-south section. This means that they were abandoned within the same time span. In general, the storage structures are characterised by a rather distinctive process of filling, with an alternation of ash and charcoal layers (Fig. 25). Nonetheless, not all of these structures were in use at exactly the same time: Structure 120 cuts Structure 121 and the walls of Structures 119 and 121 do not extend to the same depth as those of Structures 120, 126 and 147 (Fig. 24).

Another area, located to the east, features four storage structures, but their configuration seems much less organized. Only the lower parts of these structures were preserved (US 152, 154, 159, 171 ), as they were partly destroyed in order to make way for Walls 135 and 137 (Fig. 20). They are of circular to ovoid shape, and the base of their walls is built of thin mud-bricks. Although they share the same building techniques, and are more or less the same size, they do not seem to participate in the broader scheme of organisation of the area, as illustrated by the variability in the amount of space between them.

In both cases, the storage structures are organised in terrace-like areas. The layers surrounding the storage structures clearly show an alternation between sub-horizontal clay and ash layers, which are $5 \mathbf{e} 10 \mathrm{~cm}$ thick. The clay layers have been deliberately flattened to form floors. On these layers, some domestic refuse (ceramic, stones, bone) has been found. This is particularly true between Wall 175 and Storage structure 147, where a $30 \mathrm{~cm}$ thick ash layer was found to contain frequent faunal remains. This layer was located under a

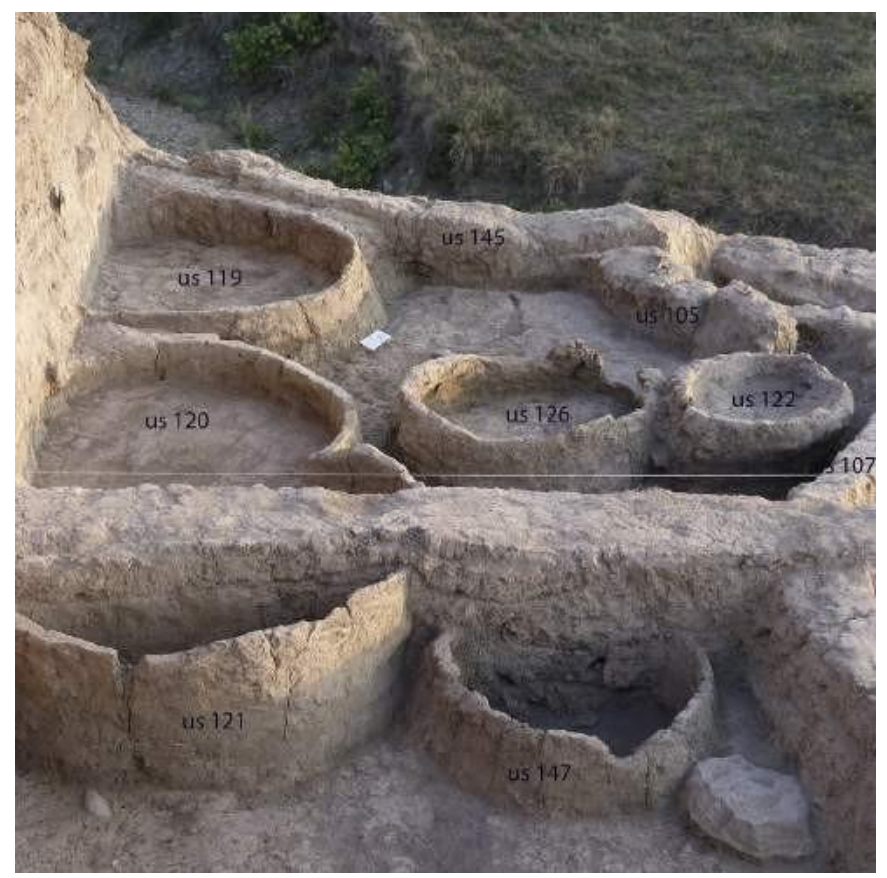

Fig. 24. Concentration of storage structures in Trench 1, view from the south (photo C. Hamon).

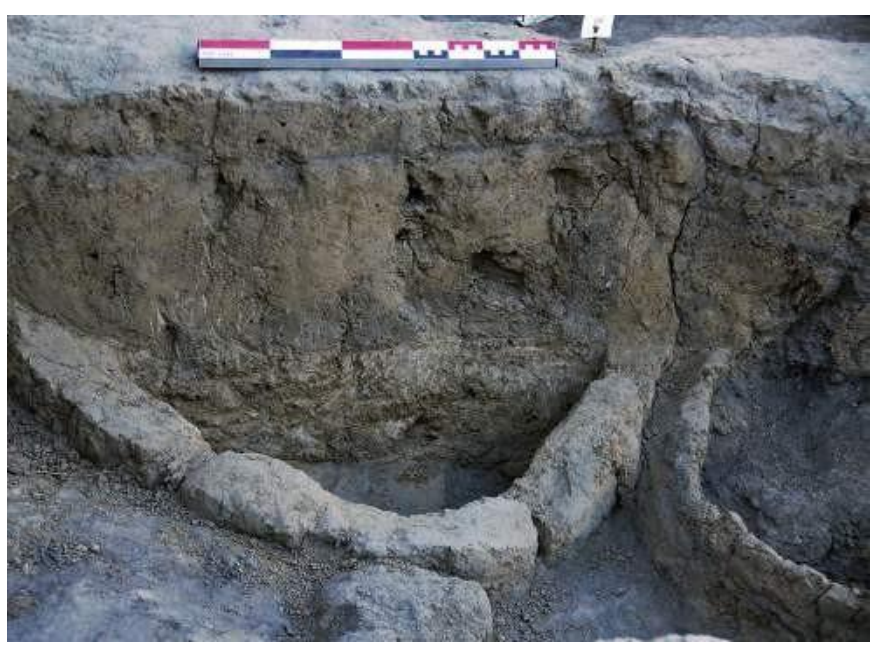

Fig. 25. Section through storage structure 121, view from the south: Note upper clay layer covering the storage structures $119,120,121$ and lower ash and clay fill layers (photo C. Hamon).

circular stone the edges of which had been shaped by flaking. The faunal remains were partly articulated and, at the base of wall 175, a complete horn was found (Fig. 26).

\subsection{Floor and soil layers}

All of the buildings and storage structures are linked to a succession of complex, dense exterior levels. The general scheme shows an alternation of clay and ash layers. The hard, compacted, sub-horizontal clay layers are interpreted as floors (when inside the buildings) or as circulation areas (when outside). The numerous cases of superposition of several floors or circulation soils probably correspond to phases of repair or resurfacing of the area. Between these levels, relatively thick layers of ash are visible. The nature of these layers has not yet been determined. Some hypotheses have been proposed but remain to be proven: The layers could, for example, represent purification activity or vegetation clearance of the spaces after a short period of abandonment. Walls 135 and 137 are constructed on one such thin ash layer, which shows that specific clay floors did not need to be prepared in order to erect new buildings. Moreover, ash layers have also been found in the areas

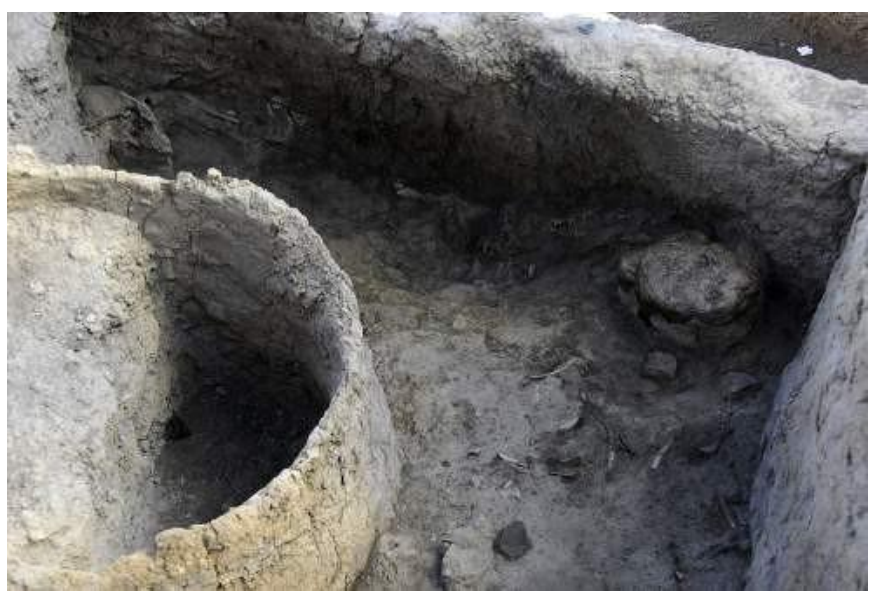

Fig. 26. Animal bone and stone refuse occurring between Structure 147 and Wall 175 Note the horn deposited against Wall 175. Trench 1, view from the west (photo C. Hamon). 
outside buildings: For example to the east of Building 135 or to the west of wall 139 (Fig. 27).

Several hearths have been discovered within these floor and circulation levels. Some consist of a simple setting of stones within which ash and charcoal have been found (US 110 and 111). A fire pit (148) has been identified just above Walls 144 and 164 (Fig. 28). The fill of this pit consists of thin ash layers, alternating with more mixed layers of charcoal, burned clay and ash. The use of this pit as a hearth (and not simply as a refuse pit) is evidenced by the occurrence of fire-reddening at the base of Wall 164 .

\subsubsection{Summary}

In Trench 1, the lowest level of occupation of the site (Horizon 2) is characterized by a high density of structures, and different phases of building and levelling, found under a sterile clay layer which is spread over much of the site.

Three parallel rows of circular buildings are oriented on an east/ west axis. The central row clearly forms part of a more recent phase than the other two. The diameters of the buildings are between 1.5 and $2 \mathrm{~m}$. They are built using different construction techniques. Some walls are constructed with regular plano-convex, mud-bricks, or with mud-bricks of variable sizes and shapes. Some walls are also built using a technique hitherto completely unknown in the Kura basin: the so-called "bauge" technique. Outside the buildings, clay floors and circulation levels alternate with ash layers, the origin of which is still unknown.

The north and south rows of building delimit an area where a high number of storage structures have been found. Two walls oriented northeast-southwest divide this area into two terrace-like zones. In the western part of the trench is an area organized around five very well-preserved "pear-shaped" storage structures. In the levels surrounding these structures, a number of refuse areas have been identified: These include deposits of faunal remains. Such a layout was previously unknown in the Kura Basin area.

The association of a high density of buildings, and destruction levels, with distinctive terrace-like areas dedicated to storage,

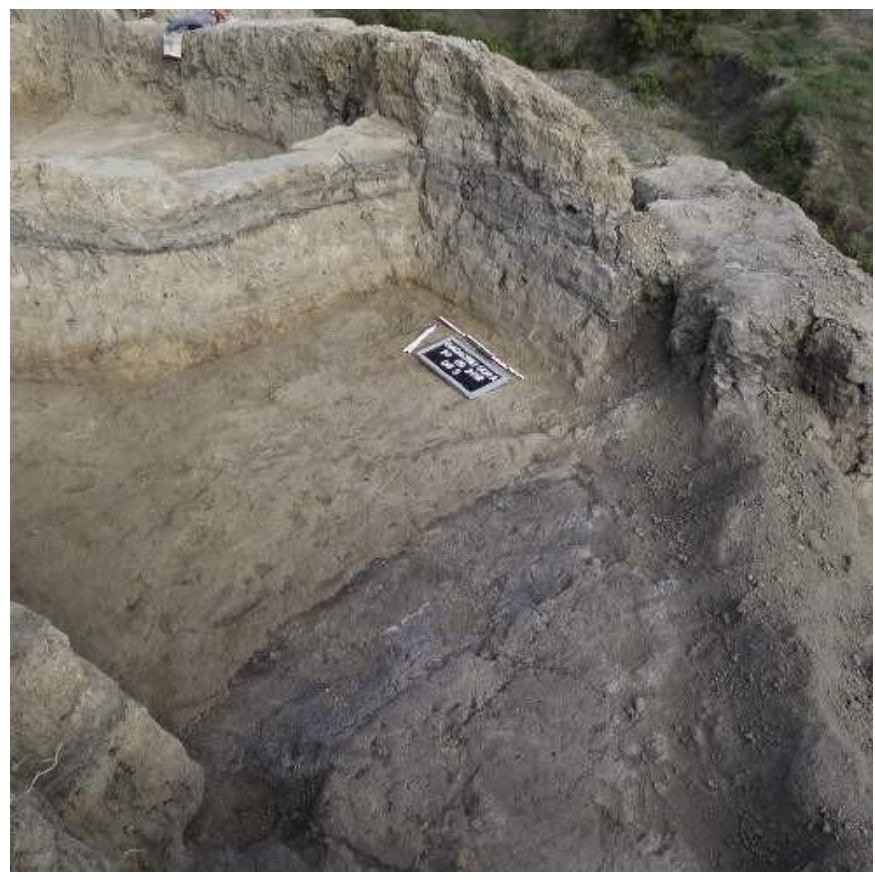

Fig. 27. Western part of Trench 1. Note the succession of ash and clay soils outside Wal 137. Trench 1, view from the west (photo C. Hamon).

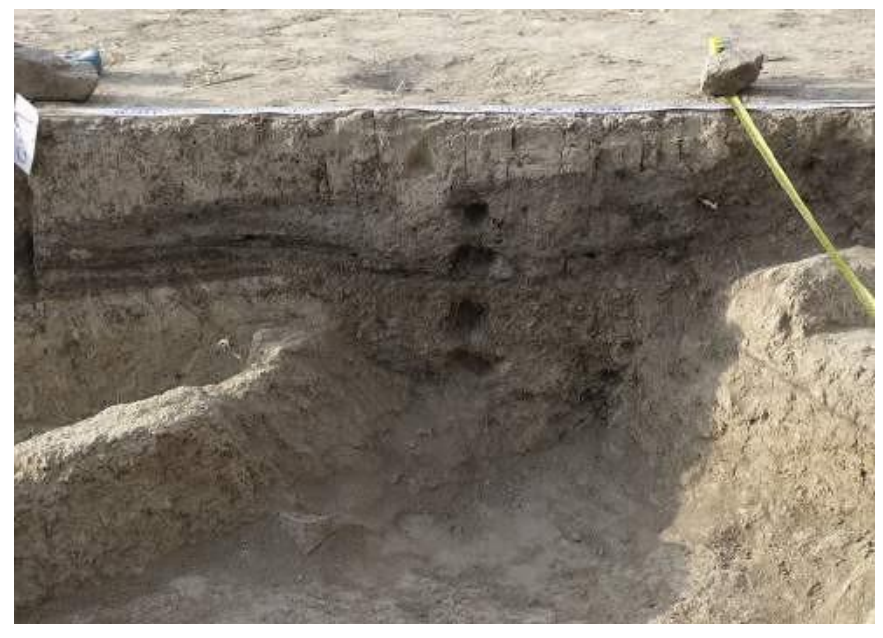

Fig. 28. Hearth in Pit 148, located between Walls 144 and 164, featuring ash fill and burnt sides. Trench 1, view from the north (photo C. Hamon).

means that Horizon 2 at Gadachrili plays an important role in our understanding of the organisation of domestic space in ShulaveriShomu culture. The coexistence of different building styles also contributes greatly to the debate on the formation processes of this culture, in terms of origin, cultural influences and formative processes.

\section{Discussion}

Two different types of organisation of the settlement area can be observed in the upper and lower horizons. First, the high density of the structures found in Horizon 1 contrasts with the wide circulation areas and larger dimensions of the Horizon 2 buildings. Such differences and evolution in the occupation of space can be interpreted in several ways. Thy might, for example, reflect the division of the space into several areas with different functions. Alternatively, they could be explained by different demographical patterns and pressures prevailing during the two occupation phases of the site. In addition, the density of the structures in Trench 1 might represent only part of Horizon 2, and correspond to a particular organisation of space in a small part of the whole settlement. In any case, the pattern represents a complete reversal of the pattern observed at Aratashen, for example, where the latest Neolithic layers are characterised by a significant densification of structures compared to the earlier levels (Badalyan et al., 2007).

In Gadachrili Gora, a real difference in spatial organisation is evident between the two horizons. In horizon 2, parallel rows of small-to medium sized circular buildings are arranged on an eastwest axis. Despite the fact that stratigraphy indicates that they are not strictly contemporaneous, it appears that this general organisation of the buildings was respected from one phase to another. The "empty" space between the two main rows of buildings was dedicated to storage. This is clearly evidenced by the erection of two rectilinear mud-brick walls oriented north-south, which delimit a true storage area. In contrast to single storage structures located inside or outside the buildings, such terrace-like storage areas were hitherto unknown in the Shulaveri group, except perhaps at Shulaveris Gora, even though they were not clearly identified as such at the time (Djavakhishvili et al., 1975). Such concentrations of storage structures within organized and specific areas are rare in the other sites of Transcaucasia. Only the site of Goytepe (Kadowaki et al., 2015), and perhaps the site of Shulaveris Gora, have yielded a similar pattern of storage structure concentrations. 
The apparent density of the settlement in Horizon 2 suggests that the potential building zone was more limited than for the later Horizon 1. A more constrained building zone could explain such density, and could, for example, be due to a difference in river levels between the two occupation horizons. A difference in the demography and number of inhabitants for each horizon could also be a factor.

In Horizon 1, the building organisation followed a different logic. The entire excavated area seems to be organized around one main, large, circular building, whose diameter is estimated to be up to six metres (this should be confirmed by further excavations). Such large building dimensions are not unknown in the ShulaveriShomu culture, but it is rare for buildings to measure more than $5 \mathrm{~m}$ in diameter, as at Shulaveri, Aruchlo or Mentesh Tepe (Djavakhishvili et al., 1975; Lyonnet et al., 2012). Positioned around the "main" building are two smaller buildings, one to the north and one to east, an arrangement which is suggestive of a cruciform layout. Such a configuration is otherwise unknown in the ShulaveriShomu culture, although certain parallels can be made with the circular layouts associating several small related circular buildings with a central courtyard, which have been revealed, for example, at Imiris Gora, Chramis Didi Gora (Djavakhishvili et al., 1975) or Goytepe (Guliyev et Nishiaki, 2010).

Such differences in the organisation of the two horizons give rise to several questions. They clearly highlight a discontinuity between the two building horizons. This might suggest that each horizon was built for a different purpose, or that a profound change in the conception of spatial organisation occurred between the two levels of occupation.

The question of the function of these two horizons is key when proposing interpretations for this complete revolution in spatial conception. In order to throw light on the subject, a programme of archaeobotanical sampling has been conducted which should help to determine the function of the storage pits and the nature of the ash and charcoal deposits between the floors. In fact, the density of storage pits has to be examined in terms of agricultural practices and the status of cereals in the economy and diet. In order to further our knowledge regarding the emergence of new agricultural practices, the site is also the focus of two projects which aim to investigate the first production of wine (Georgian Wine Agency) and the domestication of millet (ANR Orimil) in Transcaucasia.

Another question is raised by the scarcity of finds in both horizons, except within some very specific refuse areas. For the most part, the ceramic assemblage displays features already known in the Shulaveri group, as do the lithic and the bone industries. The scarcity of finds, in comparison to the other sites of the Shulaveri group, is more indicative of a deliberate and planned departure, than a sudden abandonment of the site. No in situ finds have been found, and it seems that the heaviest grinding stones and most of the ceramics were taken away from these occupation levels at the time of abandonment.

These observations lead us to question the hypothetical relationship between the four Neolithic sites of the Shulaveri group, and their role within the area. In this context it would be important to identify the dynamics linking the positions of the sites to the river and, more broadly, to the wider hydrographic basin. It is clear, for example, that the current position of the Shulaveris Ghele River does not reflect the reality at the beginning of the 6th millennium BC. It would also be interesting to determine more accurately the intensity of the "destruction" episode between Horizons 1 and 2, and how it affected not only Gadachrili Gora but perhaps also the other sites in the area. One could also ask whether the proximity of Gadachrili Gora to the river indicates that its inhabitants were looking for direct access to the river for water supply. In the absence of any systematic and large-scale dating and excavation programme for the four sites in the area, any discussion regarding the relationship between the sites will be difficult. Were these sites partly, or completely, contemporaneous? Were they complementary in terms of their economy? Were the inhabitants of the area moving from one site to another? These questions of seasonal occupation and mobility are central to this discussion (Lyonnet et al., 2012), and a number of strontium and isotope analyses have already been planned in order to throw light on this subject.

Another striking aspect of the site is the diversity of the building techniques, some of which were previously unknown in the Shulaveri group (Djavakhishvili, 1973). Such diversity in techniques brings to mind the observations made in Aratashen in the Araxe plain: Of particular note is the use of the "bauge" technique at Gadachrili Gora which could correspond to the so-called "pisé" technique observed in level II at Aratashen (Badalyan et al., 2007). However, it has not been possible to associate a specific building technique to a particular building type at Gadachrili Gora. The variety of techniques observed at the site also contrasts strongly with the homogeneity of the building techniques found, for example, in the neighbouring site of Aruchlo, where only plano-convex mudbricks of different colours have been identified (Hansen and Mirtskhulava, in Lyonnet et al., 2012). The use of plano-convex mud-bricks seems to be the most widespread and common construction technique on the Shulaveri-Shomu sites. The building technique used in Building 2004, however, is similar to certain building traditions from Central Mesopotamia and Iran. Some influences or contact between these regions have already been identified elsewhere on Neolithic sites in Transcaucasia. In the Mil steppe, for example, several elements of the ceramic assemblages are clearly related to traditions in the central Iranian plateau (Helwing in Lyonnet et al., 2012, p. 46) while some Halaf-like ceramics have been found at Aratashen in the Araxe basin (Badalyan et al., 2007, p. 40). Some influences from north-eastern Mesopotamia have also been proposed for the earliest phase of occupation at Kultepe in Naxcivan (Abibullaev, 1982), especially in terms of the architecture (Lombard et Chataignier, 2004, p. 76). However, very few "imported" elements from Iran or Mesopotamia have been found, up to now, in the middle Kura Basin. In this context, the diversity of building traditions identified in Gadachrili Gora is of central importance as it highlights the possible multiple influences and contacts that were involved in the genesis of the ShulaveriShomu culture in the northern part of Transcaucasia.

\section{Conclusion}

The excavations conducted in Gadachrili Gora have revealed several novel developments in the Shulaveri group at the beginning of the 6th millennium BC. The organisation of the settlement is reminiscent of the plan of the neighbouring sites of Shulaveri and Imiris, but also features novel elements. The existence of a large main building with secondary cells around it, arranged in a crosslike plan, is of particular interest. Another interesting aspect of the site is the existence of delimited terraces, dedicated to storage structures, located in the space between two east/west ranges of round buildings. Such features were unknown in the Shulaveri culture prior to the Gadachrili excavation. They indicate diversity in the conception of intra-site spaces within the Shulaveri group.

The coexistence of different building techniques in the two horizons is one of the main discoveries brought to light by the Gadachrili excavation. The coexistence of different patterns of mudbrick walls is the first feature to underline: the bricks display different forms (square, plano-convex, moulded or otherwise) and dimensions, and are laid in different patterns depending on the walls. In addition, the existence of walls constructed of "bauge" is very significant as this technique was hitherto unknown in the 
Shulaveri group. Such variability in the building technics clearly suggests close contacts with the Araxe basin and, further afield, with northern Iran and Mesopotamia. It contrasts clearly with the homogeneity of the building techniques generally found on the middle Kura Basin sites up to now.

The site of Gadachrili Gora provides key elements for our understanding of the influences and processes of neolithisation which led to the adoption of a production economy in the Kura basin. Further investigations should clearly focus on the status of the site and its relation with the other tells within the area, in terms of chronology, economic complementarity and landscape exploitation. New archaeological investigations focusing on the whole area will no doubt improve our knowledge of the rise and development of agriculture in Transcaucasia.

\section{Acknowledgments}

Our warm thanks go to G. Broux, D. Dolaberidze, M. Eloshvili, S. Godziashvili, F. Pichon (students, University Javakhishvili in Tbilisi, Paris 1 and Paris 4) and G. Javakhishvili (GNM), who actively contributed to the 2012 and 2013 archaeological campaigns. The excavations have received financial support from the Georgian Wine Agency, the LIAGates(CNRS-GNM), the ANR « Kurain Motion » (B. Lyonnet dir.), the ANR Orimil (E. Herrscher dir.) and the UMR 8215 Trajectoires (Cnrs).

\section{References}

Abibullaev, A.A., 1982. Eneolit i Bronza na Territorii Nakhichvanskoi. Elm, Baku. Arimura, M., Badalyan, R., Gasparyan, B., Chataigner, C., 2010. Current Neolithic Research in Armenia. Neo-Lithics 1 (10), $77 \mathbf{e} 85$.

Aurenche, O., 1977. Dictionnaire illustré multilingue de l'architecture du ProcheOrient ancien, pp. $138 \mathbf{e} 139$

Badalyan, R., Lombard, P., Avetisyan, P., Chataigner, C., Chabot, J., Vila, E., Hovsepyan, R., Willcox, G., Pessin, H., 2007. New data on the Late Prehistory of the Southern Caucasus. The excavations at Aratashen (Armenia): preliminary report. In: Lyonnet, B. (Ed.), Les cultures du Caucase (VIeeIIIe millénaires avant notre ère. Leurs relations avec le Proche-Orient. CNRS éditions, Paris, pp. $37 \mathbf{e} 61$.

Badalyan, R., Harutyunyan, A., Chataigner, C., Le Mort, F., Chabot, J., Brochier, J.E. Balasescu, A., Radu, V., Hovsepyan, R., 2010. The settlement of AknashenKhatunarkh. A neolithic site in the Ararat plain (Armenia): excavation Results 2004e2009. TÜBA-AR 13 (2010), 185e218.

Djavakhishvili, A., 1973. Stroitel'noe delai arkhitektura poselenij juzhnogo Kavkaza V-Ill tys. do n.e., Tbilisi.

Djavakhishvili, A., Kiguradze, T.V., Glonti, I., Djaparidze, O., Avalishvili, G., Davlianidze, C., Dolaberidze, R., 1975. OtchetKvemo-Kartlijskoj arkheologicheskoj ekspeditsii (1965e1971 gg) [Report on Kvemo-Kartli Archaeological Expedition (1965e1971) in Georgian]. Metsniereba.

Guliyev, F., Nishiaki, Y., 2010. Excavations at the Neolithic settlement of G6ytepe, the middle Kura Valley, Azerbaijan, 2008e2009. In: Matthews, R., Curtis, J. (Eds.), Proceedings of 7th ICAANE, Vol. 3: Fieldwork and Recent Research. Harrassowitz Verlag, Wiesbaden, pp. $71 \mathbf{e} 84$.

Hamon, C., 2008. From Neolithic to Chalcolithic in the Southern Caucasus: economy and macrolithic implements from Shulaveri-Shomu sites of Kwemo-Kartli (Georgia). Paleorient 34 (2), 85e136.

Hansen, S., Mirtskhulava, G., 2012. The neolithic settlement of Aruchlo. Report on the excavations in 2009e2011. Arch6lologische Mitteilungen aus Iran und Turan 44, $58 \mathbf{e} 86$.

Kadowaki, S., Maher, L., Portillo, M., Albert, R.M., Akashi, C., Guliyev, F., Nishiaki, Y., 2015. Geoarchaeological and palaeobotanical evidence for prehistoric cereal storage in the southern Caucasus: the Neolithic settlement of G6ytepe (mid 8th millennium BP). Journal of Archaeological Science 53 (2015), 408e425.

Kantor, H., 1978. Choga Mish and Choga Banut. Iran 16, $189 \mathbf{e} 191$.

Kiguradze, T., 1986. Neolithische Siedlungen von Kvemo-Kartli, Georgien. C.H. Beck. Kiguradze, T. Menabde, M., 2004. The Neolithic of Georgia. In: Sagona, A. (Ed.), A View from the Highlands, Archaeological Studies in Honour of Charles Burney, Ancient Near East Studies, Supplement 12. Peeters, pp. 245 e 398.

Lombard, P., Chataigner, C., 2004. Le Néolithique et le Chalcolithique en Transcaucasie : l'exemple des bassins de la Kura et de l'Araxe. In: Guilaine, J. (Ed.), Aux marges des grands foyers du Neolithique : périphéries débitrices ou créatrices, collection "Séminaires du Collège de France ». Errance, Paris, pp. $61 \mathbf{e} 84$

Lyonnet, B., Guliev, F., Helwing, B., Aliyev, T., Hansen, S., Mirtskhulava, G. (Eds.), 2012. Ancient Kura 2010e2011: the First Two Seasons of Joint Field Work in the Southern Caucasus, 44. Arch pp. $1 \mathbf{e} 190$

Narimanov, I.N., 1987. Kul'tura drevnejshego zemledel'chesko-skotovodcheskogo naselenija Azerbaidzhana (epokha Eneolita VI-IV tys. do n. e.). Elm, Bakou (in Russian).

Niebieridze,

L.,

1986.

Ranniyestupenirazvitjazapadnozakavkazskojranezemledelcheskoj kul'tury [The Development of Agriculture in Western Caucasus]. Metsniereba, Tbilisi.

Oates, J., 1969. Choga Mami 1967e1968. A preliminary report. Iraq 31, $115 \mathbf{e} 152$.

Roux, J.L., Cammas, C., 2010. Les techniques constructives en bauge dans l'architecture protohistorique de Lattara (milieu du Ve-milieu du IVe s. av. n.è). Lat$\operatorname{tara} 21,219 \mathbf{e} 288$. 